\title{
The taxonomic status of the genus Hubertoceras Spath: A new light on sexual dimorphism from the Callovian ammonites of Kutch, India
}

\author{
Rakhi Dutta, Subhendu Bardhan, Shubhabrata Paul, and Subhronil Mondal
}

\begin{abstract}
The genus Hubertoceras was described under the subfamily Proplanulitinae from the middle to upper Callovian (Middle Jurassic) beds of Kutch. Recently we revisited the Kutch Proplanulitinae and proposed a new endemic subfamily Sivajiceratinae for them. The new subfamily consists of the genera Sivajiceras, Kinkeliniceras, Obtusicostites and Hubertoceras. Development of sexual dimorphism was widespread in Jurassic ammonite families and at the same time, there was a significant increase (especially from the Callovian) of isolated sexual variants, which could not easily be paired up. In the present endeavour, we have explored the status of Hubertoceras in the light of sexual dimorphism. The genus Hubertoceras is characterised by small adult size, evolute shell with biplicate ribs and well-preserved lappets, which speak for its microconchiate nature. We have also made an attempt to identify the probable antidimorph of Hubertoceras from the contemporary large genera with evolute shells described from Kutch.

Detailed morphological and morphometrical analyses indicated that Obtusicostites is likely the macroconchiate counterpart of Hubertoceras. The HubertocerasObtusicostites pair satisfied all the paleobiological as well as geological prerequisites to form antidimorphs. Evolutionary trends between macroconchs and microconchs within the Sivajiceratinae lineage also showed parallelism.

Most of the Callovian ammonite genera of Kutch were strongly dimorphic. Intense competition for food, habitat and mates perhaps forced these genera to undergo character displacement. While the macroconchs remained less diverged being uniformly large, evolute and strongly ornate; the microconchs showed wide interspecific variation in the shape of lappets, some even lacked peristomal modifications. Different types of lappet or absence of it perhaps facilitated easy mate recognition system among other functions.
\end{abstract}

Rakhi Dutta, Department of Geological Sciences, Jadavpur University, Kolkata-700032, India, rakhi.geol@gmail.com

Subhendu Bardhan, Department of Geological Sciences, Jadavpur University, Kolkata-700032, India, sbardhan12@gmail.com

Dutta, Rakhi, Bardhan, Subhendu, Paul, Shubhabrata, and Mondal, Subhronil. 2017. The taxonomic status of the genus Hubertoceras Spath: A new light on sexual dimorphism from the Callovian ammonites of Kutch, India. Palaeontologia Electronica 20.2.37A: 1-23 palaeo-electronica.org/content/2017/1954-antidimorph-of-hubertoceras

Copyright: August 2017 Palaeontological Association. This is an open access article distributed under the terms of AttributionNonCommercial-ShareAlike 4.0 International (CC BY-NC-SA 4.0), which permits users to copy and redistribute the material in any medium or format, provided it is not used for commercial purposes and the original author and source are credited, with indications if any changes are made.

creativecommons.org/licenses/by-nc-sa/4.0/ 
Shubhabrata Paul, Department of Applied Geology, Indian Institute of Technology (Indian School of Mines), Dhanbad-826004, India, shubhabrata2005@gmail.com

Subhronil Mondal, Department of Geology, University of Calcutta, Kolkata-700019, India, subhronil.m@gmail.com

Keywords: Hubertoceras (Ammonoidea); systematic position; sexual dimorphism; Middle Jurassic; Kutch, India

Submission: 27 October 2016 Acceptance: 21 July 2017

\section{INTRODUCTION}

\section{One "has to be extremely careful when it comes to maintaining sexual relationships between hitherto blameless ammonites" (Lehmann, 1971)}

Sexual dimorphism in ammonites was established since the origination of the Order Ammonoidea during the Devonian (see Makowski, 1962, 1963; Davis et al., 1996; Page, 2008; Klug et al., 2015). Only a few Paleozoic and Triassic families (five) showed dimorphism in terms of size and shape variation (Klug et al., 2015 and references therein). From the Jurassic onward sexual dimorphism became widespread. Out of 53 Jurassic families, sexual dimorphism occurred in at least 38 families (about 72\%; see Callomon, 1963, 1969, 1981; Donovan et al., 1981; Davis et al., 1996; Klug et al., 2015), and the same trend persisted in the Cretaceous when out of 55 families sexual dimorphism was recorded in 37 families (about $67 \%$; see Wright et al., 1996, Davis et al., 1996; Klug et al., 2015). Callomon (1963) provided detailed account of sexual dimorphism in many Jurassic ammonite families, for example, Graphoceratidae and Hildoceratidae of the Toarcian (Lower Jurassic) and Hammetoceratidae (Lower-Middle Jurassic). Howarth (1992) provided an account of dimorphism in the family Hildoceratidae from the Toarcian of Britain. Page (2008) mentioned the cryptic development of sexual dimorphism in the family Phylloceratidae of Lower Jurassic.

Many of the Callovian genera of Kutch ammonites are also found in Europe where many workers established sexual dimorphism in them. For example, Callomon (1963) established macro- and microconchs within the genus Macrocephalites Zittel, 1884 of England. Theirry (1978) also provided detailed account of sexual dimorphism in the genus Macrocephalites of the lower Callovian of Europe. Cariou $(1980,1984)$ elaborately dealt with the development of sexual dimorphism within the Middle Jurassic Reineckeiidae from Europe. Cox
(1988) studied English Callovian perisphinctid ammonites and established sexual dimorphs in many genera. In a series of papers, Bardhan along with others also established sexual dimorphism in species from Kutch of different groups, e.g., Macrocephalitinae (Bhaumik et al., 1993; Datta et al., 1996), Eucycloceratinae (Jana, 2002; Jana et al., 2005), Reineckeiidae (Kayal and Bardhan, 2005), Hecticoceratinae (Roy and Bardhan, 2007), Phylcticeratinae (Bardhan et al., 2010), Pseudoperisphinctinae (Bardhan et al., 2012), Perisphinctinae (Roy et al., 2012) and Sivajiceratinae (Dutta and Bardhan, 2016; also see Callomon, 1993).

During the Jurassic, the nature of sexual dimorphism in ammonites took a turn in a new direction where microconchs had new kinds of mature modifications near aperture. The maximum number of dimorphic taxa with mature modifications in microconchs appeared during the Middle Jurassic. In the Jurassic antidimorphs, microconchs are relatively evolute and strongly ornamented with varying degrees of egression of the body whorl (Callomon, 1963, 1981).

Bardhan and Chattopadhyay (2003) attributed the great radiation of ammonites in the Jurassic to the nature of sexual dimorphism. Since two sexual variants within a species can be quite disparate, the ammonite taxa showed higher intraspecific variability. These facilitated rapid evolution. Stanley (1979) emphasized that sexual reproduction as well as sexual selection played a very important role in macroevolution. Bardhan and Chattopadhyay (2003) also related the rapid evolutionary diversification of ammonites with Mesozoic Marine Revolution (see Vermeij, 1977, 1987). The sudden increase of durophagous predation exerted much pressure on the prey communities of the shallow shelf areas, and ammonites responded against this selection pressure by strengthening their shell sculpture (Ward, 1981; Vermeij, 2002; Bardhan and Chattopadhyay, 2003; Zuschin et al., 2003; Kerr and Kelley, 2015). The great diversification 
and increasing strength of ornaments in ammonites were perhaps possible because ammonite evolved a new kind of sexual selection i.e., strong and ornamental dimorphism.

Spath (1931) described the subfamily Proplanulitinae from the Middle Jurassic of Kutch. He included genera like Cutchisphinctes Spath, 1931, Sivajiceras Spath, 1930, Obtusicostites Buckman, 1921, Kinkeliniceras Buckman, 1921 and Hubertoceras Spath, 1930 within this subfamily. No major revisionary work was completed on this subfamily after that of Spath (1931). We recently redesignated the Kutch Proplanulitinae into a separate, endemic subfamily Sivajiceratinae and considered the European Proplanulitinae as its sister group (Dutta and Bardhan, 2016). Sivajiceratinae has been characterised by evolute macroconchiate genera (Sivajiceras, Obtusicostites and Kinkeliniceras). They have strong primary ribs furcating at the middle part of the flank and septal sutural patterns are complex. Microconchs (Hubertoceras) are lappeted, evolute and strongly ribbed. Cutchisphinctes was quite unrelated to the other four genera.

Earlier, Waagen (1875) and Spath (1931) while describing many species of Hubertoceras, occasionally mentioned the presence of lappets in some of them, but did not discuss the paleobiological significance of lappets. In the absence of any underlying hypothesis, many paleobiologically important features would escape notice of the concerned workers (cf. Gould and Vrba, 1982). Curiously, Arkell et al. (1957) in the Treatise described the genus Hubertoceras without lappets although the referred figure of the holotype (figure 403.2a, b) showed the presence of a prominent lappet in $H$. omphalodes, which spoke for its microconchiate status (cf. Callomon, 1963). Most of the species of Hubertoceras described by Spath (1931) were small with biplicate ribs and some of them also possessed lappets.

We here explored the actual taxonomic status of Hubertoceras. During the Callovian, Kutch was inhabited by many large (exceeding $150 \mathrm{~mm}$ diameter), evolute genera (for example, Choffatia Siemiradzki, 1898; Indosphinctes Spath, 1930; Idiocycloceras Spath, 1928; Reineckia Bayle, 1878; Sivajiceras Spath, 1930; Obtusicostites Buckman, 1921 and Kinkeliniceras Buckman, 1921) whose inner whorls are more or less similar to adult Hubertoceras, which is small in diameter (maximum diameter $=83 \mathrm{~mm}$ ). One of the criteria of sexual dimorphism is based on the identity of the early ontogeny of putative sexual dimorphs, which have different adult stages and adult size. Much new information recently emerged in working out dimorphic pairs in ammonites (see Davis et al., 1996; Klug et al., 2015). We here explored all possibilities of finding out the true sexual counter part of Hubertoceras.

\section{GEOLOGICAL SETTING}

During the Late Triassic to Early Jurassic, the origin of the Kutch Basin took place as a result of the Gondwana fragmentation (Biswas, 1977). The fossiliferous Bathonian-Callovian sediments are extensively exposed in the mainland of Kutch, particularly in Jumara, Keera, Jara and Jura in the NW of Bhuj, the district town of Kutch as well as in LerFakirwadi and other areas situated south of Bhuj (Figure 1). The dome-shaped outcrops were formed due to successive tectonic activity and present outstanding fossil-bearing sections (Wynne, 1872).

The depositional setting of the Chari Formation, the main fossil-yielding unit was a shelf environment represented by the widespread development of siliciclastic ramp deposits, which includes different sub environments (Fürsich et al., 2004). The lower Callovian beds of the Chari Formation consist mainly of the shale-limestone association (packstone or wackestone), which suggests the outer ramp environment. The middle Callovian beds are dominantly siliciclastic and represent a shoaling upward phase (Datta, 1992; Fürsich and Oschmann, 1993). An alternation between greenish grey shale, occasionally gypseous and white fossiliferous limestone are characterised by the upper Callovian beds. Here, the sediments were deposited below the storm wave base in low energy environment within the outer ramp (Fürsich et al., 2004).

All the specimens (including types and the present collection) of the species of the subfamily Sivajiceratinae came from different localities within the mainland of Kutch (Waagen, 1875; Spath, 1931; Dutta and Bardhan, 2016) (Figure 1). The main geological sections are Jumara and Keera and other sections are Fakirwadi, Medisar, Badi, Gudjinsir, Walakhavas, Ler, etc. (for detailed stratigraphy/locality information and measurement list, see Appendix 1). In the present study, we tried to establish antidimorphic pairs between the species of Obtusicostites and Hubertoceras genera. We, therefore, made a detailed analysis of the precise stratigraphy and locality information of the all specimens of Obtusicostites and Hubertoceras. 


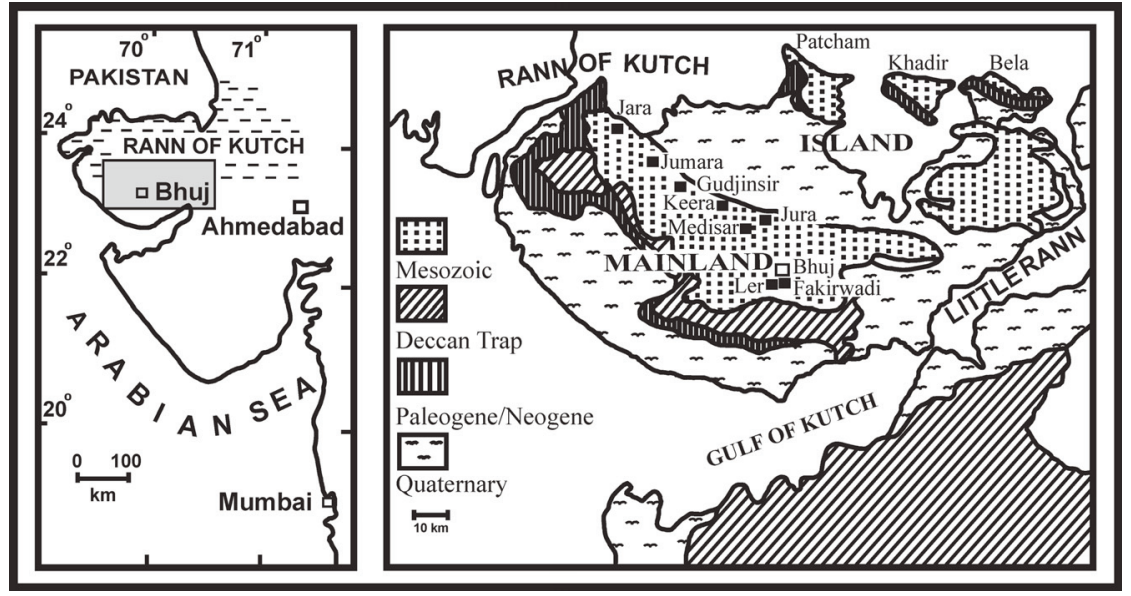

FIGURE 1. Geological map of Kutch showing the major localities (solid squares) from where fossils of the Sivajiceratinae have been collected (modified after Dutta and Bardhan, 2016).

The majority of the specimens of Obtusicostites and Hubertoceras came from the north of Bhuj sections like Jumara (24.5\%), Keera $(17.5 \%)$ and Jara $(7 \%)$ (see Figure 1). The other main sections yielding specimens include Ler, Fakirwadi, Walakhavas and Samatra (collectively $28 \%$ ), which are very closely spaced and are situated south of Bhuj. All the type specimens of Obtusicostites obtusicosta came from the 'anceps' and 'athleta' beds of Spath (1931). These beds spanned the middle to upper Callovian. In Jara, Jumara and Keera sections, we followed the high resolution lithostratigraphy recently made by Jana et al. $(2000,2005)$. Our precise collection from these sections also indicates the similar range of $O$. obtusicosta like the type specimens. Similarly a majority of specimens (including the types and the present collection) of different species of Hubertoceras, which were considered here as the antidimorphs of $\mathrm{O}$. Obtusicosta, came from the same areas from where specimens of $O$. obtusicosta were also collected. The northern sections yielded most of the specimens (Jumara-33\%, Keera-20.8\% and Jara-4\%) and the southern section collectively yielded $8 \%$ of the specimens (Fakirwadi-4\% and Vanda-4\%). Some specimens (25\%), however, do not have any locality or stratigraphic information. Stratigraphic distribution of Hubertoceras specimens suggests that they were also essentially coeval with Obtusicostites specimen, i.e., ranging from the middle to upper Callovian (for detailed stratigraphic/locality information, see Appendix 2). Another species of Obtusicostites is O. Devi, and it is represented by 3 macroconch and 3 microconch specimens, all of which are type specimens. Most of the specimens came only from a single locality, Fakirwadi and horizon, i.e., 'athleta' bed (Spath, 1931; also see Appendix 2). The above discussions suggest that the alleged antidimorphic pairs of $O$. obtusicosta and $O$. devi essentially co-occurred and had the same locality distribution in Kutch.

The stratigraphic and locality information and measurements of other genera of different families, which have been studied here for comparison, are listed in Appendix 3. The stratigraphic distributions of the studied species of the subfamily Sivajiceratinae of Kutch are shown in Figure 2.

\section{MATERIAL AND METHODS}

Our study material comprises the type specimens $(n=40)$ and the present collection $(n=174)$. We included specimens of Sivajiceratinae described from other region within the Indo-Madagascan Faunal Province (e.g., Collignon, 1958) in our analyses. The type specimens of Waagen (1875) and Spath (1931) are archived in the repository of the Geological Survey of India, Kolkata, India and Natural History Museum, U. K. The type specimens are mostly collected from Keera and Jumara sections (see Figure 1). The present collection is archived in the museum of Geological Sciences, Jadavpur University, Kolkata, India.

\section{Search for the Taxonomic Status of Hubertoceras in the Light of Sexual Dimorphism.}

Spath (1931) described the genus Hubertoceras from Kutch. He altogether included six species: $H$. omphalodes (Waagen, 1875), $H$. dhosaense (Waagen, 1875), H. hubertus Spath, 1931, H. arcicosta (Waagen, 1875), H. mutans (Waagen, 1875) and $H$ ? sp. nov. Spath, 1931 (Fig- 


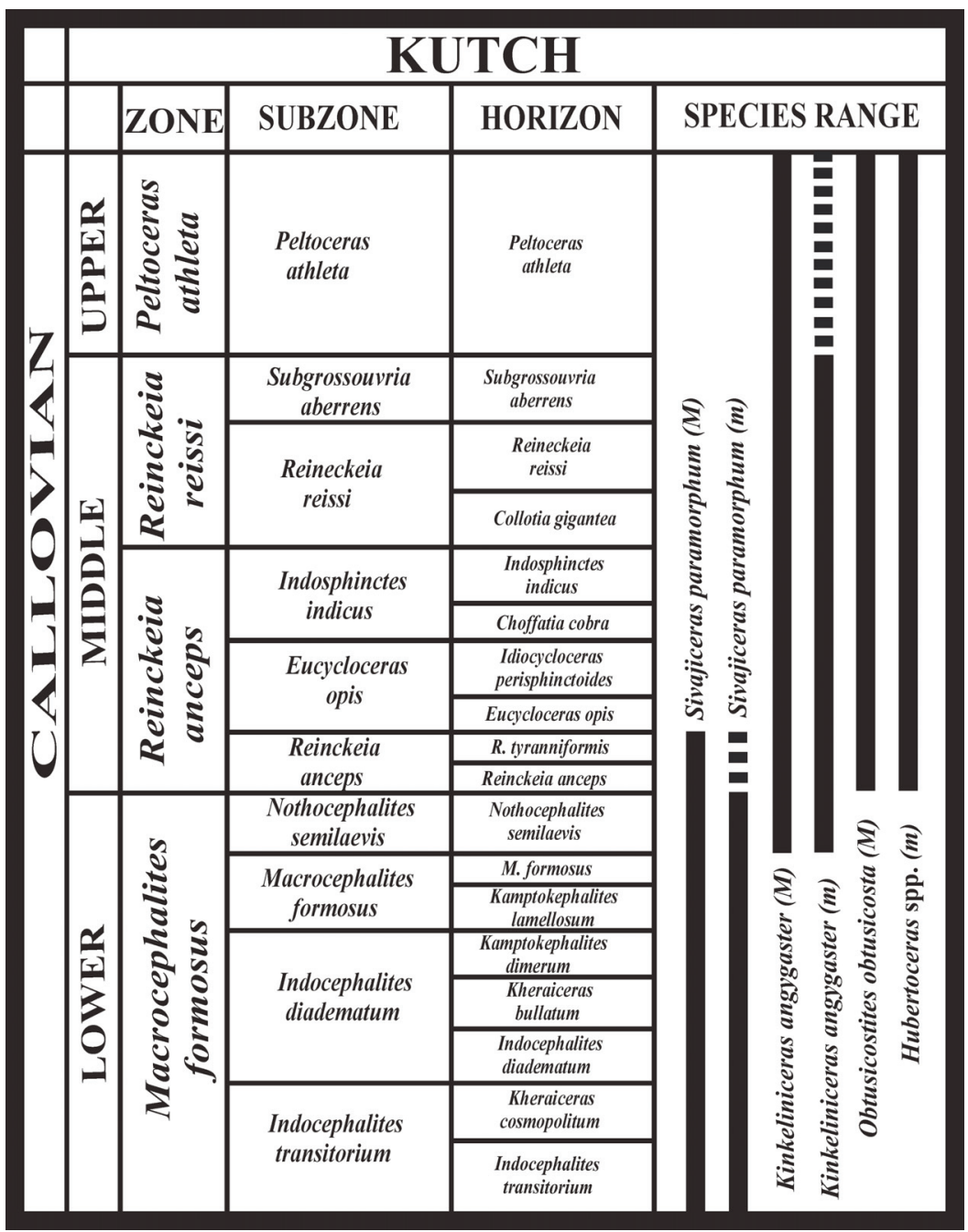

FIGURE 2. The stratigraphic distribution of the studied antidimorphic pairs under the subfamily Sivajiceratinae of Kutch. Biozonation after Jana et al. (2000, 2005); Bardhan et al. (2012).

ure 3). He incorporated a few species of Waagen (1875) described under the genus Perisphinctes. Spath (1931) provided some diagnostic characters of Hubertoceras which are: biplicate ribs that occasionally disappeared on the venter and lacked thickened primary ribs; its species were evolute and compressed in adult stage with simplified suture (Spath, 1931; p. 284). We studied all the species described by Spath (1931) based on the type material obtained from several localities and horizons within the middle to upper Callovian of the mainland of Kutch. Our revision of the Hubertoceras spp. revealed that ribs never disappear on adult body whorl and in many cases, primary ribs are thickened to form bullae (see Figure 3.1, 3.3). Out of six species, the type specimens of three species have preserved lappets (i.e., $H$. omphalodes, $H$. dhosaense, $H$. hubertus) (see Figure 3.1-
3.7), and the rest are nearly complete with terminal constrictions preserved (Figure 3.8-3.10).

The holotype of $H$. arcicosta (Waagen, 1875, plate 58 , figure 2$)$ is a small adult shell $(D=67 \mathrm{~mm})$ and is reproduced here in Figure 3.9. Spath (1931, plate 79 , figure $1 \mathrm{a}, \mathrm{b}$ ) provided another specimen of $H$. arcicosta with adult body chamber. In both specimens peristomal margins are not preserved. Although Spath (1931) included $H$. arcicosta within the genus Hubertoceras, it was found from the lower Callovian beds of Kutch. While mentioning the stratigraphic range of Hubertoceras, he categorically wrote 'the genus Hubertoceras was thus proposed for forms of the anceps and athleta beds (= middle to upper Callovian)' (Spath, 1931, p. 284). Because of this stratigraphic assignment as well as some morphological differences (for example, dense primary and secondary ribs), $H$. 


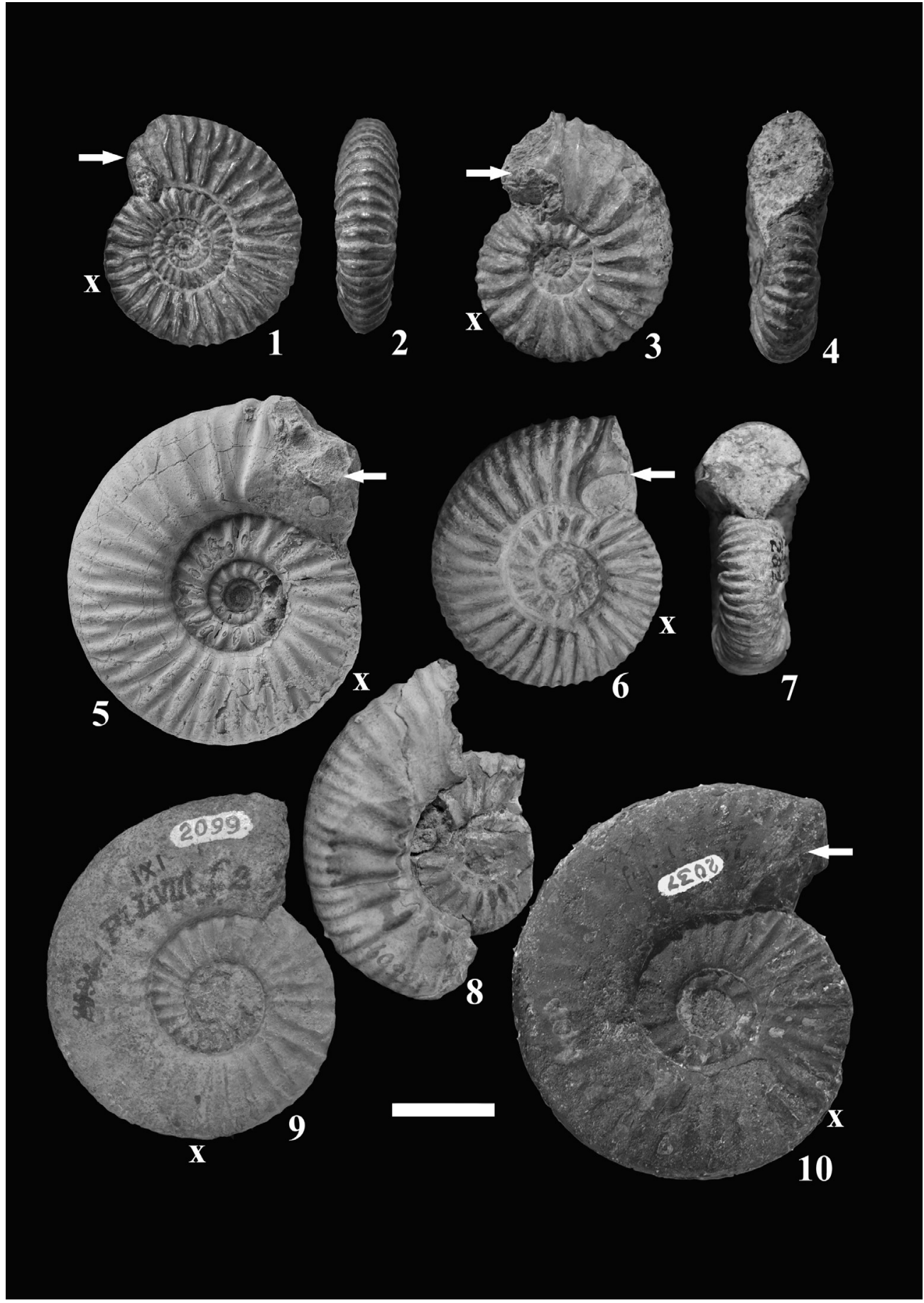

FIGURE 3. Representatives of Hubertoceras described by Spath (1931) from the Callovian of Kutch. 1-2. Holotype of Hubertoceras omphalodes (Waagen), GSI no. 2030, lateral and ventral views; 'Perisphinctes anceps beds' of Vanda (=middle Callovian anceps beds). 3-4. Holotype of $\mathrm{H}$. dhosaence (Waagen), GSI no. 2035, lateral and apertural views; 'Perisphinctes anceps bed' of Keera (=beds nos. 5-7 of middle Callovian). 5. Holotype of $H$. hubertus Spath; NHMUK no. C7686, lateral view. 6-7. H. hubertus var. densicostata, GSI no. 16098, lateral and apertural views; ?anceps beds of unknown locality. 8. H? sp. nov.; GSI no. 16099, lateral view; athleta beds of Fakirwadi (=athleta beds of upper Callovian). 9. Holotype of $H$. arcicosta, GSI no. 2099, lateral view; 'Golden Oolite' of Keera (=bed no. 2 of lower Callovian). 10. Holotype of $H$. mutans; GSI no. 2037, lateral view; 'Katrol group' of North Gudjinsir. Beds are following Jana et al. $(2000,2005)$. Commencement of body chamber and presence of lappets are indicated by ' $x$ ' and arrows respectively. GSI=Geological Survey of India, NHMUK=Natural History Museum, U.K. Scale bar equals $20 \mathrm{~mm}$. 
arcicosta had been provisionally excluded from the Hubertoceras sensu stricto (see also Dutta and Bardhan, 2016). It was rather closer to the microconch of Kinkeliniceras, which first appeared in the lower Callovian and was included here within Kinkeliniceras. Hubertoceras mutans (Waagen, 1875) is a problematic species both from morphological and stratigraphic reasons. The holotype of $H$. mutans is a small adult shell $(D=83 \mathrm{~mm})$ with entirely preserved outer whorl. Waagen (1875) mentioned that the ribbing of the holotype was "very faint on the body chamber, and it is almost impossible to count them" (p. 152). Perhaps he meant that it was biological and not due to the abrasion or lack of the shell remains. Stratigraphically, it came from the base of the 'Katrol Group' of the Oxfordian age (see also Spath, 1931), which is not within the range of Hubertoceras s. st. Even the Katrol Formation was not within the Oxfordian, it actually belongs to the Kimmeridgian (Shome and Bardhan, 2009). But Spath (1931) was confused with the stratigraphy of some of the specimens, which he illustrated as $H$. mutans (Spath, 1931, plate 54 , figure $8 a$, b; plate 56 , figure $7 a$, b; plate 60 , figure $1 a, b$ ). The specimen (plate 54 , figure $8 a$, b) which came from the younger Oxfordian may not belong to Hubertoceras. Another specimen (plate 56 , figure $7 a, b)$ is highly compressed and relatively involute. He was not sure about its stratigraphic occurrence and mentioned its occurrence questionably from his 'anceps beds'. It is both morphologically and morphometrically similar to microconch of the older Kinkeliniceras (personal observation). One specimen (Spath, 1931, plate 57 , figure $6 \mathrm{a}, \mathrm{b}$ ) came from the 'anceps' horizon proper and is quite similar to Hubertoceras s. st. Spath (1931) also reiterated that it "is more like $H$. omphalodes than the type" (p. 318). We here synonymised it with the type species, $H$. omphalodes. Hubertoceras? sp. nov. is represented by a single specimen whose early part of outer whorl is broken, but the latter half consists of terminal whorl and Spath (1931, p. 323) mentioned "the mouth border almost intact except for the lateral processes" (see Figure 3.8). However, we found the mouth border broken and ribs are occasionally trifurcating in the outer whorl. We, in a previous attempt, considered it as the young phragmocone of Obtusicostites (Dutta and Bardhan, 2016) and here placed it within Obtusicostites devi.

All the species of Hubertoceras, therefore appeared to be small and lappeted or adult with nearly complete body chamber with lappets missing. They varied in size ranging from $45 \mathrm{~mm}$ to 83 $\mathrm{mm}$ with adult body whorl consisting of about three-fourths of the outer whorl. All species have biplicate ribs. This suggests that Hubertoceras is a microconchiate genus (cf. Callomon, 1963). Recently we combined some of the lappeted species (H. omphalodes, $H$. dhosaense and $H$. hubertus) of Spath (1931) within a single species, $H$. omphalodes (Dutta and Bardhan, 2016). They represent intraspecific variants and are essentially contemporaneous. Ontogenetically, Hubertoceras shows variation in shell involution (umbilical diameter/shell diameter i.e., $U / D=0.33-0.43$ ), shell inflation (whorl width/whorl height i.e., W/H $=0.7-1.09$ ) and ornamental density (primary ribs, $\mathrm{P}=7-15$; secondary ribs, $S=16-29$ ) (Dutta and Bardhan, 2016).

\section{Search for the Macroconchiate Counterpart of Hubertoceras}

Klug et al. (2015) followed Davis et al. (1996) in formulating criteria to identify antidimorphic pairs. The important ones are: 1) a supposed dimorphic pair must be distinguished by at least one morphological trait (i.e., adult size, ornament, suture, etc.); 2) in a cladistic sense, the supposed pair must be monophyletic and forms a sister group; 3) they should be paleobiogeographically and paleoecologically congruent and; 4) secondary sexual features should be preserved in the shell for example, rostra, lappets, etc. Identical juvenile ontogeny is also very important prerequisite for proposing a hypothesis of sexual dimorphism. While looking for the possible macroconch of Hubertoceras, we kept all these criteria in mind.

Although the Callovian ammonites are among those which are best known in terms of sexual dimorphism, there remained a significant percentage of doubtful cases of sexual dimorphism from the Callovian to the Kimmeridgian (Davis et al., 1996). This situation was partly attributed to the rise in the numbers of microconch ammonoids that were very hard to pair up with any macroconchiate forms if the stratigraphic ranges and paleobiogeographic patterns were considered. Similarly, it was challenging to establish the macroconchiate counterpart of Hubertoceras. Our search for the macroconchiate counterpart of Hubertoceras included the genera within the Sivajiceratinae lineage as well as macroconchs of some other coeval genera of different lineages. We considered other genera because of the existence of great morphological disparity between dimorphs of a single biological species. They were often previously placed as distinct species within different taxonomic groups (e.g., see Callomon, 1963; Klinger and Kennedy, 
1989; Jana et al., 2005). For this purpose, we have carried out extensive morphological and morphometrical comparisons. Two quantifiable characters like the whorl shape $(\mathrm{W} / \mathrm{H})$ and coiling (U/D) have been measured in Hubertoceras and all species of the potential macroconchiate genera.

The beginning of the middle Callovian in Kutch witnessed a rapid diversification of many large, evolute and ornamented ammonite macroconchite genera, including Reineckeia (Cariou and Krishna, 1988; Kayal and Bardhan, 2005); Choffatia (Bardhan et al., 2012); Idiocycloceras (Jana et al., 2005), Indosphinctes etc. These macroconchiate genera also show general similarity in shape (evolute) and nature of ornaments (strong ribs) with the macroconchiate genera of Sivajiceratinae lineage. We explored the possibility of finding the true macroconchiate counterpart of Hubertoceras within any of the above mentioned genera and Sivajiceratinae (Figures 4-5). For this we made bivariate plots (R-plots) involving degree of inflation (W/ $H)$ vs. degree of involution (U/D) of all these genera, including Hubertoceras $(n=180)$.

\section{Methods for Establishing Parallel Evolution}

Another important prerequisite for establishing sexual dimorphism in a lineage is that both macroconch and microconch of the member species should show parallel evolution through time. Parallel evolution may be even found at higher taxonomic level between two distinct lineages (for example, see Monnet et al., 2011). Callomon (1963) considered this phenomenon within species as the strongest evidence in favour of sexual dimorphism. According to him, "the lineages must develop in pairs, in parallel like railway lines" ( $p$. 33).

Evolutionary trends of different morphological characters of each dominant species within each genus of Sivajiceratinae are analysed. Median values of quantifiable characters like shell diameter (D), degree of involution (U/D), degree of inflation $(\mathrm{W} / \mathrm{H})$, number of primary $(\mathrm{P})$ and secondary $(\mathrm{S})$ ribs per half whorl are plotted for both macroconchs and microconchs based on sizable number of specimens $(n=110)$. Complete adult body whorl diameters of many macroconch specimens are not available. We, therefore, measured either the diameter of the incompletely preserved body chamber or reconstructed the diameter from the trace of the umbilical seam of body whorls. We counted primary and secondary ribs, from the adult phragmocones of specimens because in some species for example, Sivajiceras paramorphum, the secondary ribs disappear on the adult body chamber. Parallel evolution between sexual dimorphs is expected to be persistent even within a lineage. We, therefore, tested this hypothesis at the genus-level incorporating all species of Sivajiceratinae of the Callovian. Sivajiceras is represented by $S$. paramorphum and two species of Kinkeliniceras ( $K$. angygaster and $K$. subwaageni) and two species of Obtusicostites (O. obtusicosta and $O$. devi) are considered. We also tested this hypothesis at the species level for the genus Sivajiceras and Obtusicostites. Sivajiceras were represented by two species, i.e., S. congener of the upper Bathonian and $S$. paramorphum of the lower-middle Callovian and Obtusicostites also represented by two species, i.e., O. obtusicosta and $O$. devi of the middle and upper Callovian. We could not establish antidimorphic pairs in all species of Kinkeliniceras and it was therefore excluded from the analyses.

\section{RESULTS}

\section{Search for Macroconch of Hubertoceras Outside Sivajiceratinae}

Reineckeia anceps has evolute and inflated shell with strong tubercles, but the inner whorls lack tubercles and have bifurcating ribs (Cariou and Krishna, 1988; Kayal, 2009) like Hubertoceras (compare Figures 4.1 and 5.6). Numerous sharp primary ribs $(P=12$ at about the diameter of $13 \mathrm{~mm})$ are the characteristic feature of inner whorls of $R$. anceps whereas in Hubertoceras, the primary ribs are strong and widely spaced $(\mathrm{P}=8$ at about $21 \mathrm{~mm}$ diameter). However, this macroconch does not match with Hubertoceras since it is distinctly sulcate at the mid-venter, a typical symplesiomorphic character of the family Reineckeiidae. Difference in subfamily level affinity is also evident in the sutural patterns. The first lateral lobe in Reineckeia is extremely long and slender ending with one branch (see Waagen, 1875, plate 58, figure 1b), whereas the first lateral lobe in Sivajiceratinae has five long terminating branches. Morphometrically, the macroconch of $R$. anceps is also quite distinct from Hubertoceras (Figure 6). Moreover, paleobiogeographically, Hubertoceras is restricted only to the Indo-Madagascan Faunal Province (Dutta and Bardhan, 2016), while Reineckeia comes from many regions including Kutch, Europe, South America, North Africa, etc. (Arkell et al., 1957; Cariou, 1984) and has a longer stratigraphic range (upper Bathonian to entire Callovian). Recently, Kayal (2009) established the dimorphism in 


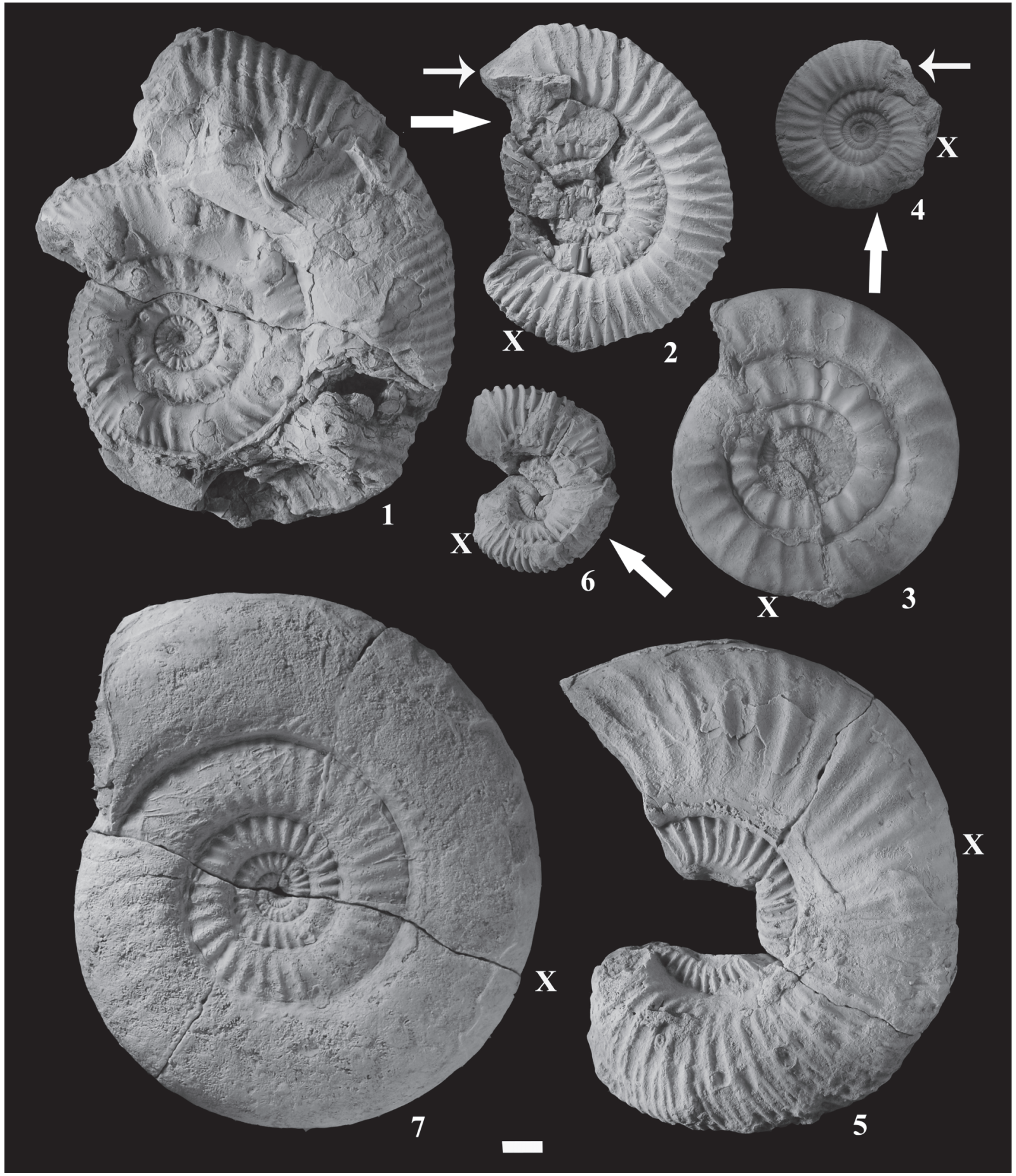

FIGURE 4. Different sexual dimorphic ammonites (non-Sivajiceratinae) contemporary to Hubertoceras during the middle Callovian in Kutch. Sexual Dimorphism among these species is well established and the pairs have been shown to be connected by large arrows. 1-2. Reineckia anceps (M, JUM/R/90, bed 6, middle Callovian of Keera and m, JUM/R/44, bed 9, middle Callovian of Jumara, respectively). 3-4. Choffatia cobra (M, JUM 33, bed 7, lower Callovian of Jumara and m, JUM 38, bed 7, lower Callovian of Jumara respectively). 5-6. Idiocycloceras perisphinctoides (M, JUM 450, bed 8, middle Callovian of Jura and m, JUM 270, bed 6, middle Callovian of Keera respectively). 7 . J Indosphinctes sp. (M, JUM/IS/01, bed 11, middle Callovian of Jumara). Beds are following Jana et al. (2000, 2005). Note that microconch of Indosphinctes is still unknown. ' $x$ ' indicates the end of phragmocone. Small arrow indicates presence of lappets. Scale bar equals 20 mm. The sources are: Jana et al., 2005; Kayal, 2009; Bardhan et al., 2012, Dutta and Bardhan, 2016. 


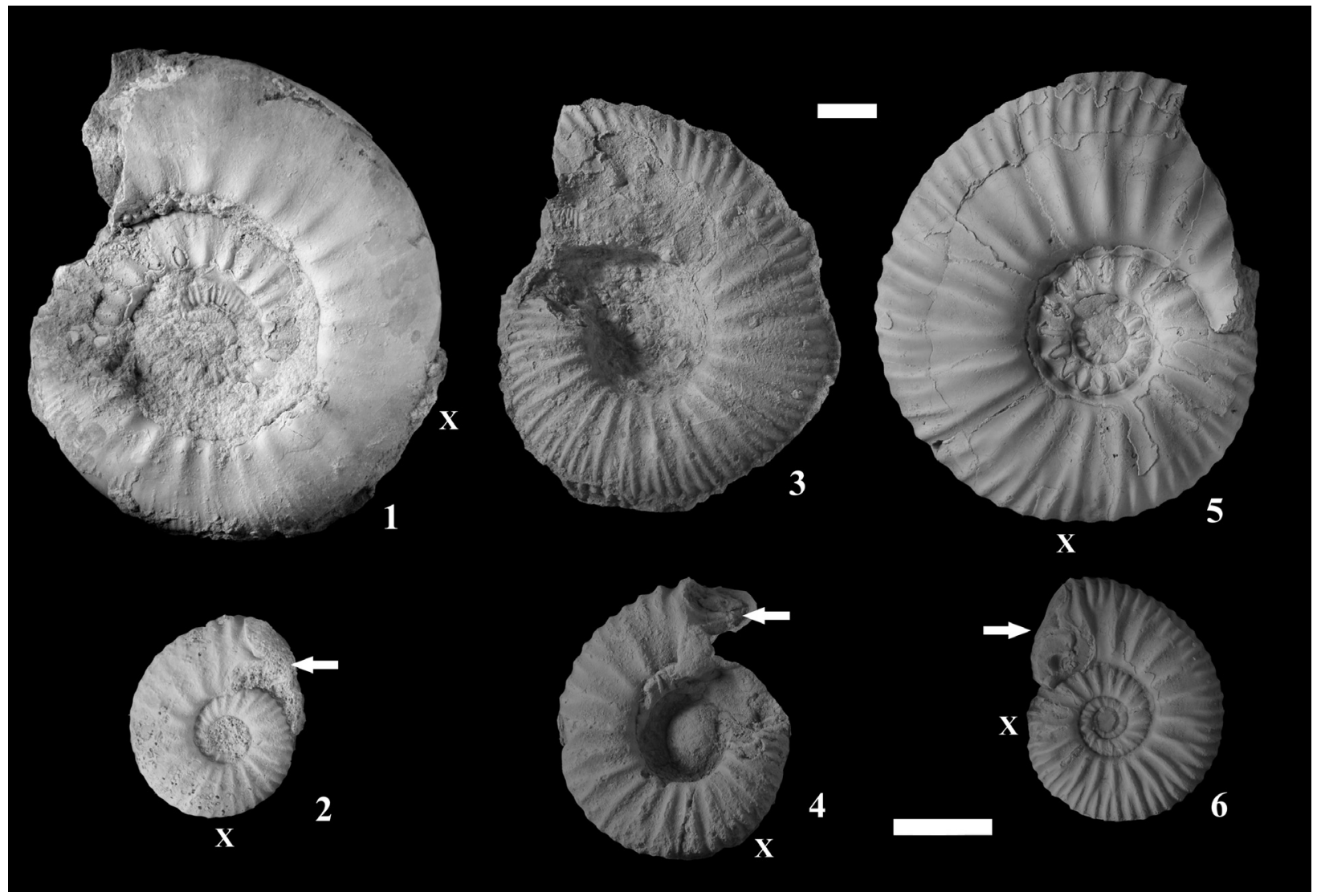

FIGURE 5. Supposed antidimorphic pairs within the subfamily Sivajiceratinae. 1-2. Sivajiceras paramorphum (M, JUM /SP/2, bed 7, lower Callovian of Jumara and $\mathrm{m}$, JUM/SP/22, bed 2, lower Callovian of Keera). 3-4. Kinkeliniceras angygaster (M. JUM/KA/1, locality/stratigraphy unknown; m. JUM/KA/5, Medisar, Jura). 5-6. Obtusicostites obtusicosta (M, JUM/OO/1, bed 11, middle Callovian of Jumara and m, JUM/OO/14, locality/stratigraphy unknown). ' $x$ ' indicates the end of phragmocone. Small arrow indicates the presence of lappets. Scale bars=20 mm. The sources are: Jana et al. (2000, 2005) for stratigraphic information and Dutta and Bardhan (2016) for taxonomy.

Reineckeia in Kutch where macroconch and microconch match well with each other (see Figures 4-5) and the microconch is quite distinct from Hubertoceras.

Another abundant and diverse genus of the middle Callovian is Choffatia. The type species $C$. cobra is characterized by evolute, depressed whorls with strong primary ribs (Figure 4.3) furcating at the outer flank. Their inner whorls are somewhat similar to inner whorls of Hubertoceras in having strong primary ribs and perisphinctoid umbilicus (shallow and wide). However, detailed examination revealed that there are many apomorphies of Choffatia not shared by Hubertoceras. For example, constrictions are present in the inner whorls of C. Cobra which are lacking in Hubertoceras. The number of secondary ribs in Choffatia and their points of furcation also vary from that of Hubertoceras (for detailed description of Choffatia cobra, see Bardhan et al., 2012). The sutural pat- tern of Hubertoceras broadly resembles that of Choffatia cobra (see Bardhan et al., 2012; figure $13 \mathrm{~b}$ ), but septal sutures are more ramified and complex in the later. Morphometrically, they are also disjunct (Figure 6). Bardhan et al. (2012) established antidimorphic pairs in Choffatia (see Figure 4.3-4.4) of Kutch in which microconchs are lappeted. But, Choffatia microconchs differ from Hubertoceras in many characters (e.g., ribbing patterns, number of ribs and shape of lappets) (Figure 4.4). Their paleobiogeographic distributions also suggest inhomogeneity; while Hubertoceras is endemic to Kutch and neighbouring areas, Choffatia in contrast, is widely distributed throughout the world. It is found in Africa (Tanzania, Ethiopia), Madagascar, Kutch, Europe (Italy, Spain, France, England), North and South America (Alaska, British Columbia, Mexico, Chile, Argentina) and central Asia (Turkmenistan) (Bardhan et al., 2012). Stratigraphically, Choffatia is long ranging (Batho- 


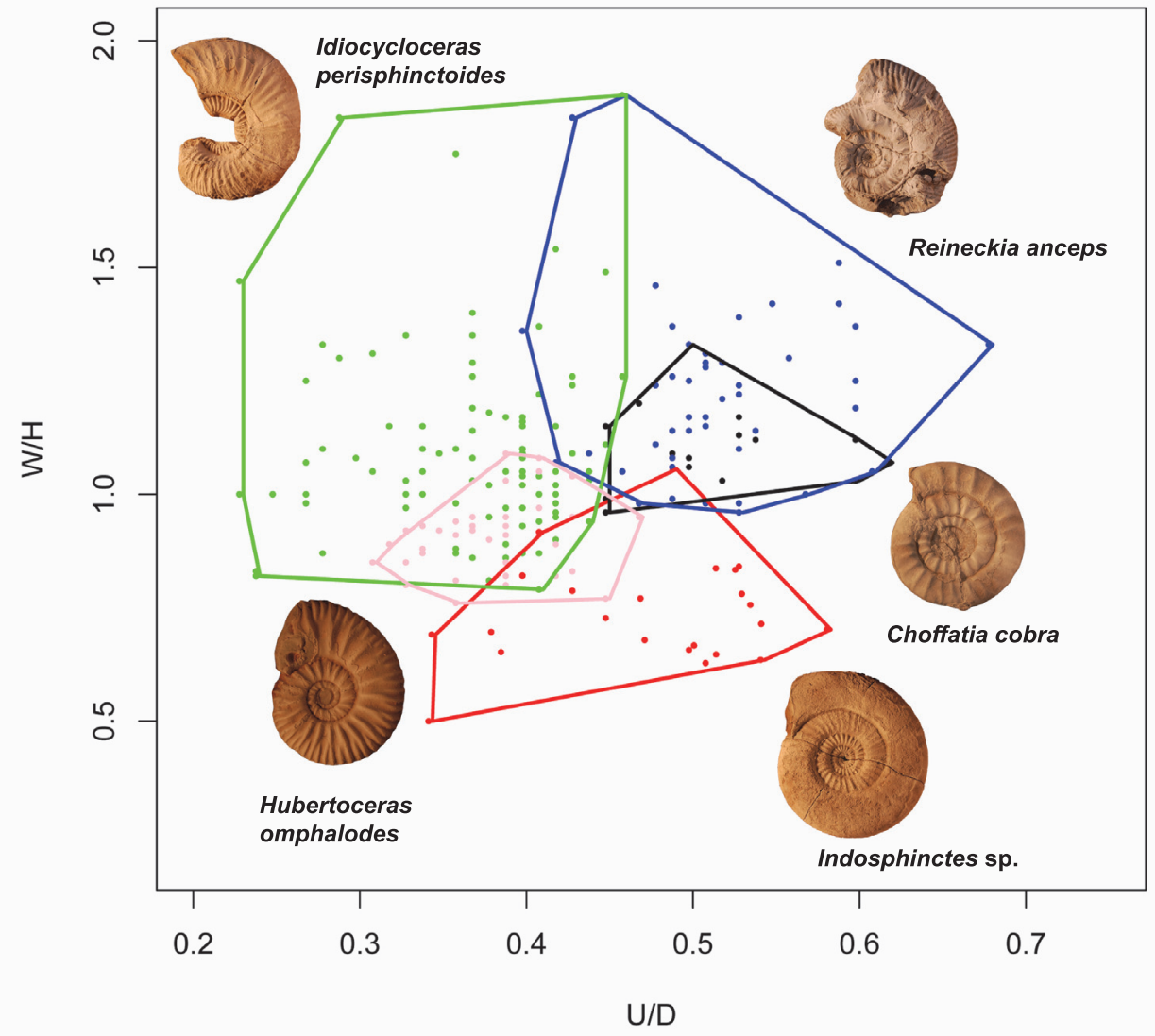

FIGURE 6. Bivariate growth graphs between Hubertoceras omphalodes and macroconchs of all contemporary (middle Callovian) species of different genera i.e., Reineckia anceps, Choffatia cobra, Idiocycloceras perisphinctoides and Indosphinctes sp. Cluster of morphological characters of Hubertoceras are separated from those of other genera. $\mathrm{D}=$ Diameter of the shell, $\mathrm{U}=\mathrm{Umbilical}$ diameter, $\mathrm{W}=$ Width of the whorl and $\mathrm{H}=$ Height of the whorl. Measurements are taken at different ontogenetic stages of the specimens to accommodate intraspecific range of variability of each species. Photos are not to scale.

nian-Callovian) while Hubertoceras is restricted only to the middle and upper Callovian.

Similarly, for the case of Idiocycloceras the macroconchiate data do not fit with Hubertoceras. Idiocycloceras (M) is characterised by its more evolute, depressed to compressed whorl shape with distant primary ribs which are blunt, straight and finally disappear near the peristome (Figure 4.5). The whorl shape of Idiocycloceras in the inner part is compressed to depressed whereas Hubertoceras always have depressed inner whorls. Idiocycloceras have some overlapping areas with Hubertoceras (Figure 6). Both Idiocycloceras and Hubertoceras, also have similar bioprovincialism. They are mainly found in the Indo-Madagascan region as well as in Himalayan Tethys (Jana et al., 2005; Dutta and Bardhan, 2016). But, Idiocycloceras is biostratigraphically well constrained and restricted only to the Idiocycloceras perisphinctoid horizon within the subzone Eucycloceras opis of the Anceps Zone in the middle Callovian of Kutch (Jana et al., 2005). Hubertoceras has a larger stratigraphic range spanning the middle to upper Callovian. Because of these stratigraphic heterochroneity and the morphological disparity, Idiocycloceras is probably not the antidimorph of Hubertoceras. Another important clue of their different subfamily level affinity comes from their entirely different sutural patterns. Septal suture in Idiocycloceras is projected towards umbilical with a broad typical saddle envelop of lobes (Jana et al., 2005, text figure 15) while in Hubertoceras, auxiliary lobes are oblique and hang down to form a broad umbilical lobe. Besides, the antidimorph of Idiocycloceras is well established (Figure 4.5-4.6; also see Jana et al., 2005); although its microconchiate counterpart has an adult body size range and degree of involution similar to those of Huber- 
toceras, the lack of lappet and nature of ribbing (strong and dense) readily distinguishes it (Figure 4.6) from Hubertoceras.

Indosphinctes is another abundant genus of the lower and middle Callovian of Kutch. Spath (1931) only described Indosphinctes from the lower Callovian beds, and we recently discovered a distinct middle Callovian species. Indosphinctes is a large genus with evolute and compressed shell and smooth body chamber (Spath, 1931; Dutta and Bardhan, 2017; Figure 4.7). Thus Indosphinctes may be a contender for the macroconchiate counterpart of Hubertoceras. Study of inner whorls, however, reveals that they are unrelated. In the inner whorls of Indosphinctes, primary ribs are dense ( $P=15$ per half whorl at the $37 \mathrm{~mm}$ diameter), whereas in the same diameter the primaries are less dense and distant in the inner whorls of Hubertoceras $(P=10)$. Moreover, furcation of ribs takes place at the higher flank in Indosphinctes whereas secondaries originate nearly at the midflank in Hubertoceras. Septal suture of Hubertoceras is very simple while it is highly complex and ramified in the genus Indosphinctes (see Dutta and Bardhan, 2017, figure 2.2). Stratigraphically, Indosphinctes spans from the lower to middle Callovian where as Hubertoceras is from the middle to upper Callovian. Paleobiogeographically, Indosphinctes is a cosmopolitan genus distributed in Europe (England, France), Africa (Kenya), Asia (Turkey, Iran), Kutch, Japan, etc. (Arkell et al., 1957; Cox, 1988), whereas Hubertoceras is restricted only to the Indo-Madagascan Faunal Province with rare occurrence in the Himalayan Tethys (Dutta and Bardhan, 2016).

\section{Search for Macroconch of Hubertoceras within Sivajiceratinae}

Sivajiceras is a member of the subfamily Sivajiceratinae and thus phylogenetically related to Hubertoceras in having similar synapomorphic characters like depressed shell and strong primary ribs in the inner whorls (Dutta and Bardhan, 2016). General similarity of sutural patterns also speaks for their affinity at the subfamily level. Sivajiceras ranges from the upper Bathonian to the lower part of the middle Callovian (Roy et al., 2007; Dutta and Bardhan, 2016). Only in the early part of the middle Callovian, these two genera overlap stratigraphically. The Callovian species of Sivajiceras is represented by $S$. paramorphum. The macroconch is characterised by highly evolute and compressed shell with a smooth venter on the adult body whorl and shows some morphometric homogeneity with
Hubertoceras (Figure 7). Spath (1931) also reiterated 'that in ribbing [Hubertoceras species] resemble the young Sivajiceras throughout life' (p. 284). We argued that this similarity is due to the fact that they were phylogenetically close. Sivajiceras has constriction in early stage which is an apomorphic character, not present in the inner whorls of Hubertoceras (see Dutta and Bardhan, 2016). We recently discovered the microconch of $S$. paramorphum from the lower Callovian horizons, which was very similar to Hubertoceras (Dutta and Bardhan, 2016). But these two microconchs differ from each other in adult size and degree of involution (Figure 5.2). Hubertoceras was larger with more evolute shell. Sivajiceras, therefore, might not be the antidimorph of Hubertoceras since it has a longer startigraphic range and has its own microconch.

Another important genus of Sivajiceratinae is Kinkeliniceras. It occurs mainly in the middle Callovian beds of Kutch. Adult Kinkeliniceras is rather relatively involute, compressed and has more number of ribs. The inner whorls of Kinkeliniceras are also involute, compressed and have denser primary ribs while the inner whorls of Hubertoceras are evolute, depressed and have distant primaries. Even the pre-adult shell of Kinkeliniceras differs from that of Hubertoceras in having a relatively involute shell with numerous fine ornamentation. In both Kinkeliniceras and Hubertoceras, sutural patterns are similar being less complex (Figure 8.4; Dutta and Bardhan, 2016, figure 6c). Morphometrically, Kinkeliniceras shows non-overlapping cluster with Hubertoceras (Figure 7). We recently described the microconch of Kinkeliniceras angygaster, which looks dissimilar to Hubertoceras in many respects (see Figure 5.4).

The genus Obtusicostites is another macroconchiate form within the Sivajiceratinae. The dominant species, $\mathrm{O}$. obtusicosta is characterised by a large, evolute shell with strong ornamentation and complex sutural patterns. The type species, Hubertoceras omphaloides, differs from it by its size being small with a less complex suture and is characterized by lappeted peristome. Obtusicostites and Hubertoceras are not only phylogenetically related, they share many apomorphic characters in their inner whorls. The depressed, evolute shell (Figure 8.1-8.2) with strong primary ribs characterises the inner whorls of both $O$. obtusicosta and $H$. omphalodes. Moreover, they have bullae-like primary ribs on the adult shells (Figure 5.5-5.6). Another dimorphic pair, $O$. devi is established by the only types. Here, microconch differs from the 


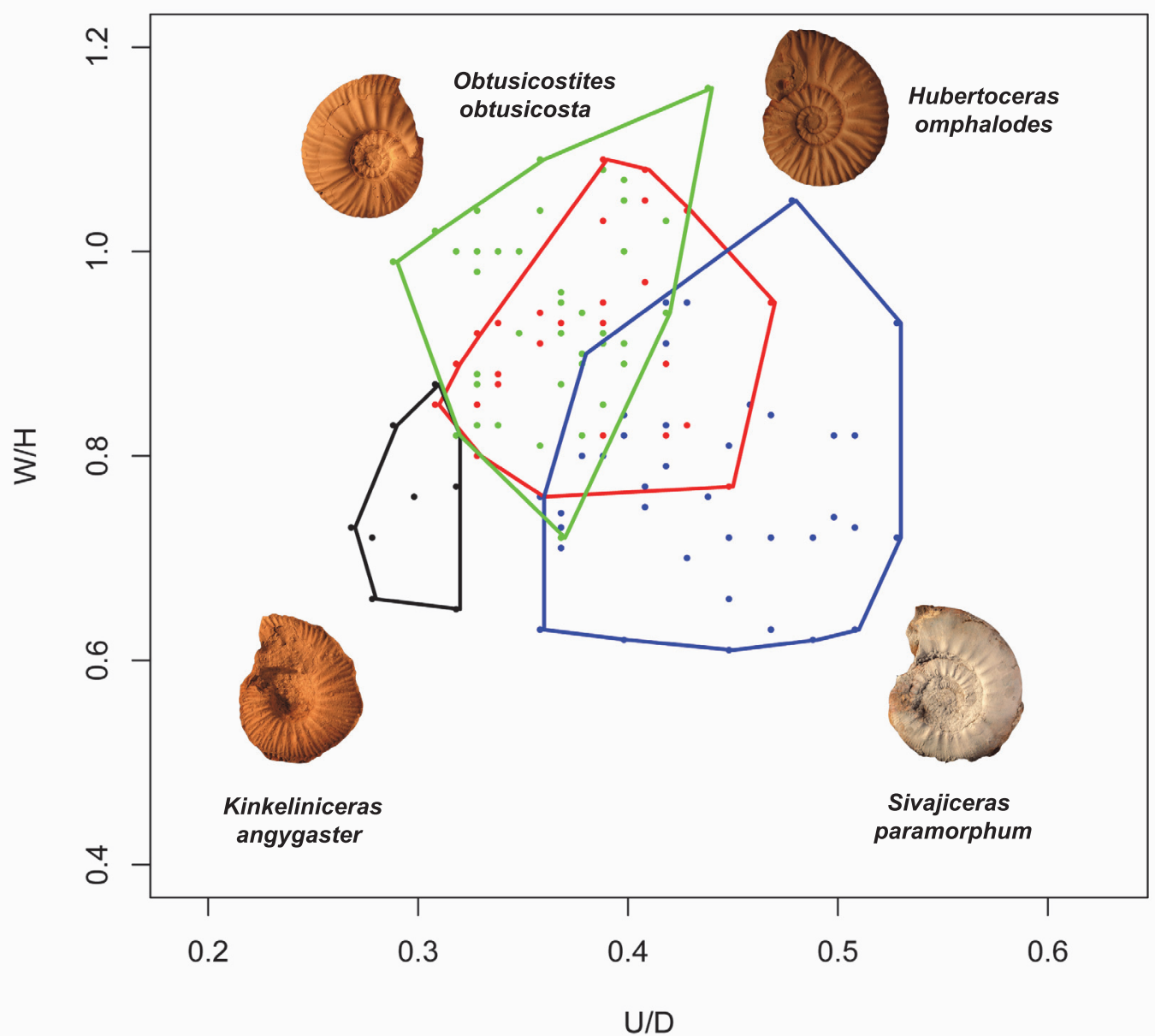

FIGURE 7. Bivariate growth graphs between Hubertoceras omphalodes and macroconchs of the subfamily Sivajiceratinae. Maximum homogeneity of points is shown between Obtusicostites obtusicosta and Hubertoceras omphalodes. $\mathrm{D}=$ Diameter of the shell, $\mathrm{U}=$ Umbilical diameter, $\mathrm{W}=$ Width of the whorl and $\mathrm{H}=\mathrm{Height}$ of the whorl. Measurements are taken at different ontogenetic stages of the specimens to accommodate intraspecific range of variability of each species. Photos are not to scale.

macroconch by its small size and lappeted peristome.

In many occasions, Spath (1931, p. 321-322) mentioned the identical nature of the inner whorls of Obtusicostites with adult Hubertoceras. For example, rounded whorl shape of adult Hubertoceras resembles the inner whorls of Obtusicostites, and there is great resemblance between the whorl thickness of Hubertoceras and the young Obtusicostites. Callomon (1963) emphasized that one of the criteria for the establishment of sexual antidimorphic pair is that the microconch is more or less the miniature version of the inner whorls of macroconch. Morphometrically, Obtusicostites shows maximum homogeneity with Hubertoceras (Figure 7) in comparison to other macroconchiate genera of middle-upper Callovian of Kutch. More importantly, they share similar paleobiogeographic (Indo-
Madagascan Faunal Province) and stratigraphic (middle to late Callovian) distributions. Ideally in any dimorphic species, sex ratio should be 1 but in ammonites it may vary 100:1 in favour of any variant (Callomon, 1981). Curiously, in the present Obtusicostites obtusicosta collection from Kutch, the sex ratio is close to $1(\mathrm{M}: \mathrm{m}=1.15: 1)$ and in case of $O$. devi the ratio is 1 . Therefore, this antidimorphic pairs satisfy all the criteria in establishing the sexual dimorphism.

\section{SYSTEMATIC PALEONTOLOGY}

Abbreviations: * in front of the publication year in the synonymy list for the name-giving citation. vin the synonymy list in front of the publication year indicates the specimens which were investigated in the present study. [M] and [m] designate macro- 
conch and microconch respectively. The following letters are used to indicate shell parameters: Ddiameter of the shell; $U$ - diameter of the umbilicus; $\mathrm{W}$ - width of the whorl; $\mathrm{H}$ - height of the whorl from the umbilical margin; $P$ - number of primary ribs per half whorl; $S$ - number of ventral ribs (secondary plus intercalatory ribs) per half whorl.

Phylum MOLLUSCA Linnaeus, 1758

Class CEPHALOPODA Cuvier, 1795

Order AMMONOIDEA Zittel, 1884

Family PERISPHINCTIDAE Steinmann, 1890

Subfamily SIVAJICERATINAE Dutta and Bardhan, 2016

Type genus SIVAJICERAS Spath, 1930

Genus OBTUSICOSTITES Buckman, 1921

Type species. Perisphinctes obtusicosta (Waagen, 1875)

Diagnosis of the genus. Macroconch large (maximum $D=165 \mathrm{~mm})$ and evolute $(U / D=0.3-0.38)$. Bullae-like primary ribs characterise the shell. Microconch (maximum $\mathrm{D}=50 \mathrm{~mm}$ ) lappeted and strongly ribbed.

Species included. Obtusicostites obtusicosta (M and $\mathrm{m}$ ) and Obtusicostites devi (M and $\mathrm{m}$ ).

Stratigraphical and geographical occurrences: middle to upper Callovian; Kutch, Madagascar Tanzania and Spiti, Himalaya.

Obtusicostites obtusicosta (Waagen, 1875)

Figures 3.1-3.4, 5.5- 5.6, 8

Holotype. GSI type no. 2032[M]

v*1875. Perisphinctes obtusicosta, Waagen, p. 146, pars, pl. 38, fig. la,b; p. 146, pl. 38, fig. 2; p. 146, pl. 38, fig. 3 a,b [M]

v 1875. Perisphinctes dhosaensis, Waagen, p. 149, pl. 38, fig. 4 a-c $[\mathrm{m}]$

v 1875. Perisphinctes omphalodes, Waagen, p. 150, pl. 38 , fig. 2 a,b [m]

v 1931. Obtusicostites obtusicosta (Waagen); Spath, pl. 55, fig. 2; pl. 64, fig. 3 a,b [M]

v 1931. Obtusicostites waageni, Spath, pl. 53, fig. 2a, b; pl. 80, fig. 1 a,b (m).

v 1931. Obtusicostites buckmani, Spath, pl. 49, fig. 9; pl. 53, fig. 3 a,b; pl. 62, fig. 8 [M]

v 1931. Obtusicostites devi, Spath, pars, pl. 45, fig. 5; pl. 52, fig. 2 a,b; pl. 65, fig. 3 [M]

v 1931. Obtusicostites devi, Spath, pars, pl. 55, fig. 4 [M]

v 1931. Obtusicostites ushas, Spath, pl. 52, fig. 6; pl. 53, fig. I a,b; pl. 56, fig. 1; pl. 57, fig. 3; pl. 63, fig. 6 [M]

v 1931. Kinkeliniceras crassiplanula, Spath, pl. 58, fig. 4, 5; pl. 65, fig. 4 a,b [M]

v 1931. Obtusicostites aff. ushas, Spath pl. 57, figs. $7 a, b[\mathrm{~m}]$ v 1931. Hubertoceras dhosaense, (Waagen); Spath, pl. 74 , figs. 50 a,b [m].

v 1931. Hubertoceras hubertus, Spath, pars, pl. 57, fig. 4a-c; pl. 59, fig. I [m]

v 1931. Hubertoceras omphalodes, (Waagen), Spath, pl. 49, figs. 7 a,b; pl. 61, fig. 4; pl. 65, fig. 2; pl. 67 , fig. 9 [m]

1958. Obtusicostites aff. obtusicosta, (Waagen); Collignon, pl. 29, fig. 133 [M]

1958. Obtusicostites ushas, (Spath), Collignon, pl. 29, fig. 131 [M]

1958. Obtusicostites. buckmani, (Spath), Collignon, pl. 31, fig. 143 [M]

1958. Obtusicostites devi, (Spath), Collignon, pl. 31, fig. 144 [M]

1958. Kinkeliniceras kinkelini, (Dacque), Collignon, pl. 29, fig. 135 [m]

\section{Description}

Macroconch. Species shows great ontogenetic changes in degree of involution and inflation. Inner whorls $(D=50 \mathrm{~mm})$, are evolute $(U / D=0.3-0.38)$ and depressed $(\mathrm{W} / \mathrm{H}=1-1.09)$. Primary ribs are very strong, fewer and distant. Intermediate whorls $(D=57-115 \mathrm{~mm})$ are still evolute $(\mathrm{U} / \mathrm{D}=0.3-0.39)$ but have more or less squarish whorl shape $(\mathrm{W} / \mathrm{H}=$ $0.8-1)$. Primary ribs furcate below the mid flank into 2 to 3 secondary ribs which go straight across the venter. Primaries are low, broad and may form bullae. The end of the adult phragmocone ( $D=124$ to $159 \mathrm{~mm}$ ) characterized by a shallow and broad constriction. Shell is compressed $(\mathrm{W} / \mathrm{H}=0.75-$ $0.81)$ and relatively less evolute $(U / D=0.32-0.38)$. Flanks are flattish with strong primary and secondary ribs. Primary ribs on the inner flank forms characteristic bullae. Umbilicus has sloping wall and gradual margin. The numbers of primary and secondary ribs vary considerably during ontogeny. They increase from $P(7-9)$ and $S(30-33)$ in the inner whorls to $P(9-11)$ and $S(33-36)$ in the adult phragmocone. The adult body chamber occupies more than half of the outer whorl and is thoroughly and relatively densely ribbed. Umbilicus has inclined wall with gradual margin. Ribs continue and show no sign of attenuation at least up to the preserved end $(D=165 \mathrm{~mm})$. Length of primaries increases in the body chamber, in the latter part of the body chamber, the primary ribs furcate higher on the flank.

The external saddle broad, with a deeply incised secondary lobe; the first lateral lobe is narrow and longer than the siphonal lobe, may have five terminating branches; the first lateral saddle is narrow with a deep asymmetrical lobe. The second lateral lobe is hanging, narrow and short. The sec- 

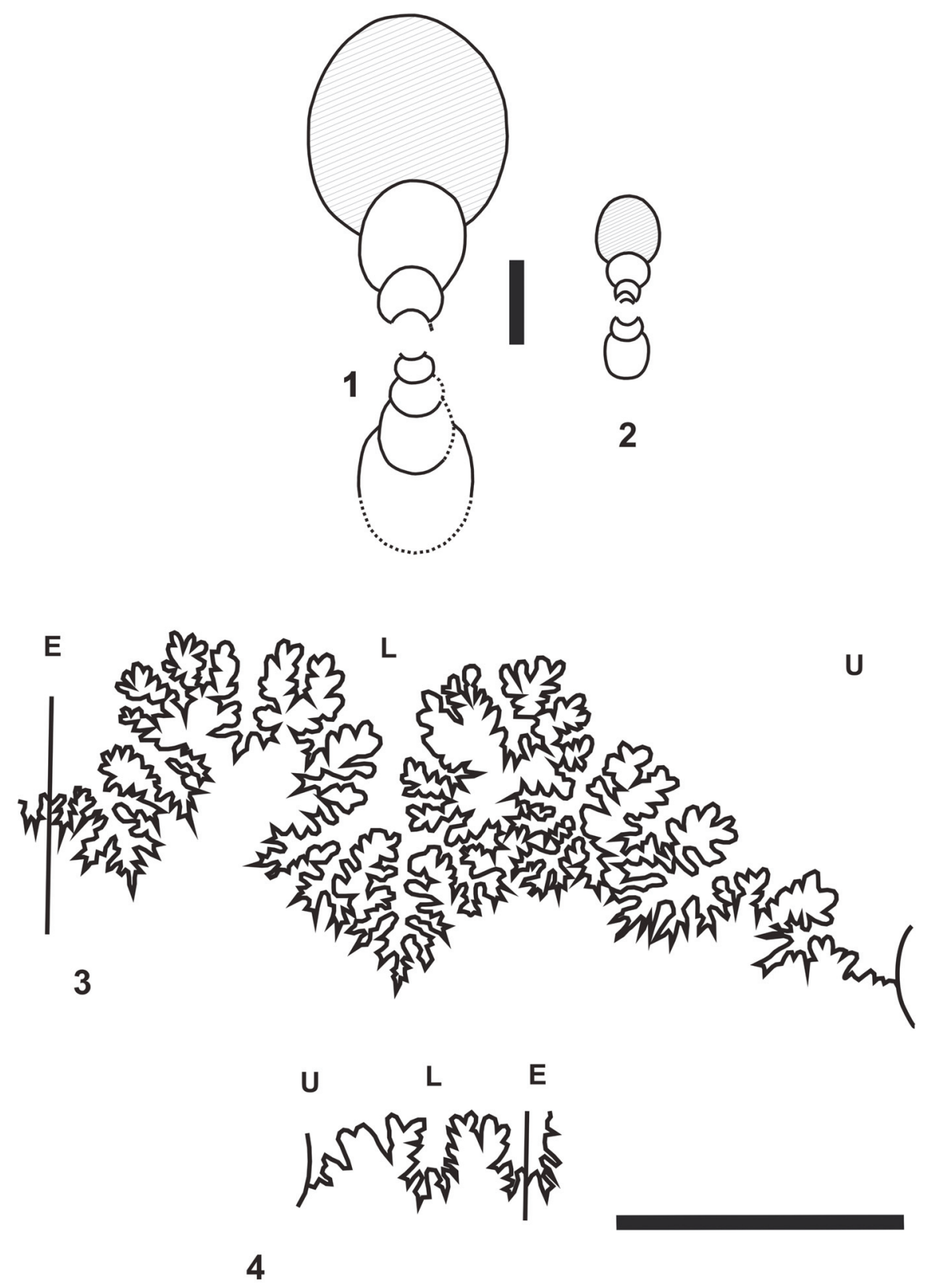

FIGURE 8. Transverse sections (body chamber hatched) of adult shells. 1. Obtusicostites obtusicosta (M). 2. Hubertoceras omphalodes $(\mathrm{m})$. Note, for 1 and 2, overall similarity of whorl sections and depressed inner whorls with rounded umbilical edge. Septal sutural patterns. 3. Obtusicostites obtusicosta (M) at diameter $150 \mathrm{~mm}$, redrawn from Waagen (1875, plate 38, figure 2). 4. Hubertoceras omphalodes $(\mathrm{m})$ at diameter $48 \mathrm{~mm}$, redrawn from Waagen (1875, plate 38 , figure 4c). Scale bar equals $20 \mathrm{~mm}$.

ond lateral saddle is also short and oblique with a very large secondary lobe. The second lateral lobe up to the umbilical suture hangs further down and forms a large umbilical lobe (see Figure 8.3).

Microconch. Inner whorls $(\mathrm{D}=7-15 \mathrm{~mm})$ are evolute $(\mathrm{U} / \mathrm{D}=0.41-0.44)$ and depressed $(\mathrm{W} / \mathrm{H}=1.05-$ 1.2). Primary ribs are strong and widely spaced.
Adult phragmocone $(D=25-37 \mathrm{~mm})$ retains the same evolute $(\mathrm{U} / \mathrm{D}=0.4-0.42)$ and depressed $(\mathrm{W} /$ $\mathrm{H}=0.95-1.09$ ) shell. Primary ribs are rectiradiate and furcate into 2 to 3 secondaries, which are prorsiradiate and passing over the venter with a forward bend. In the adult body chamber, primary ribs $(P=12$ to 15$)$ are strong bullae -like and split into 2 
secondaries at the middle to slightly higher flank. Umbilicus has inclined wall with gradual margin. Shell may be compressed to slightly depressed $(\mathrm{W} / \mathrm{H}=0.68-1.09)$ and shows wide variation in degree of involution $(U / D=0.33-0.43)$. Peristome is marked by narrow, deep, long lappet with broad base which is preceded by deep terminal constriction.

The sutural pattern is simple, but broadly resembles the pattern of that of macroconch. The siphonal lobe is broad and short; the external saddle is not very broad, with a strong indentation in the middle; the first lateral lobe is narrow, longer than the siphonal lobe, with three asymmetrical branches; the first lateral saddle is relatively narrow with an incipient but distinct lobe at the middle; the second lateral lobe is short, oblique and not yet branched. Two auxiliary lobes are oblique and hang down to form a broad umbilical lobe (see Figure 8.4).

Remarks. The inner whorls of macroconch and microconch are essentially similar being depressed and evolute shell. Both have strong primary ribs. Microconch replicates the intermediate sized macroconch in having similar ribbing pattern and strength of ornamentation. Whorl shape and coiling are also more or less similar. While adult macroconch is always compressed and evolute, the adult microconch is more evolute and may be less compressed to depressed than that of macroconch. Septal sutural patterns are broadly similar between macroconch and microconch confirming subfamilies affinities but, sutural pattern of micrococh is simple. The size ratio between macroconch and microconch $(M: m)$ is $3: 1$ and sex ratio $(M: m)$ is 1.15:1.

Obtusicostites devi (Spath, 1931)

Figure 3.5-3.7

Holotype. GSI type no. 16076[M]

v*1931. Obtusicostites devi, Spath, pars, pl. 52, fig. 5 a,b; pl. 54, fig. 1a,b (M)

v 1931. Hubertoceras? sp. nov., Spath pl. 79, fig. 4 a,b [m]

v 1931. H. hubertus, Spath, pars, pl. 52, fig. 7; pl. 69, fig. 4 a,b; pl. 56, fig. 4 ; pl. 68 , fig. 11 [m]

Remarks. This species is represented only by types. Spath (1931) described many Obtusicostites and Hubertoceras species from higher stratigraphic horizons, i.e. his 'athleta' beds (upper Callovian). These forms have flattish flanks with a shallow umbilicus and more ribs compared to the older O. Obtusicosta, which has its highest abundance in the Middle Callovian. These 'athleta' species were synonymised and assigned to $O$. devi of
Spath in the present study. They included both macroconchs and microconchs. The holotype of $O$. devi is an adult septate specimen with half of the outer whorl (missing) occupied by the adult body chamber as evident from the trace of the umbilical seam. Reconstructed diameter is $198 \mathrm{~mm}$ and is considered here as macroconch. While describing the differences of these species with $O$. obtusicosta, Spath (1931) correctly observed that $O$. devi had a weaker and denser costation of both primary and secondary ribs. In the adult phragmocone, $O$. devi has more ribs $(P=14, S=38)$ than $O$. obtusicosta $(P=11, S=36)$. Obtusicostites devi is more compressed $(\mathrm{W} / \mathrm{H}=0.67)$ than O. obtusicosta $(\mathrm{W} /$ $\mathrm{H}=0.72$ ) in the adult phragmocone stage. Septal suture is simple.

Microconch of $O$. devi (maximum D $=73 \mathrm{~mm}$ ) also has a finer and denser ribbing pattern $(P=15$, $S=38$ ). Primaries are relatively weak, and furcation takes place high on the outer flank. Both macroconch and microconch have planulate shape. The size ratio between macroconch and microconch $(M: m)$ is 2.7:1 and sex ratio $(M: m)$ is 1 .

\section{Parallel Evolution}

Evolutionary trends of macroconchs and microconchs within the Sivajiceratinae lineage broadly show parallel changes (Figure 9, Appendix 4). Degree of involution (U/D) depicted the clearest evidence of parallel evolution. The degree of involution declines significantly (Mann-Whitney $U$ Test with $\alpha=0.05$ ) between Sivajiceras and Kinkeliniceras, followed by a significant increase (MannWhitney $U$ Test with $\alpha=0.05$ ) between Kinkeliniceras and Obtusicostites. This trend is observed in both macroconchs and microconchs of the member species. In case of other parameters, although statistical significance of these changes is not always similar, directions of changes are similar in both macroconchs and microconchs.

We also tested the species level parallel evolution. For the genus Sivajiceras, the macroconchs and the microconchs of the two species i.e. S. congener and $S$. paramorphum show more or less parallelism of the diameter, degree of involution, degree of inflation, primary and secondary ribs (Figure 10). Same patterns are followed by the two species of Obtusicostites, i.e., O. obtusicosta and O. devi (Figure 11).

Moreover, new evolutionary characters for example, bullae-like primary ribs simultaneously appeared in the macroconch (Obtusicostites obtusicosta) and microconch (Hubertoceras omphalodes), and the number of ribs increased in the 

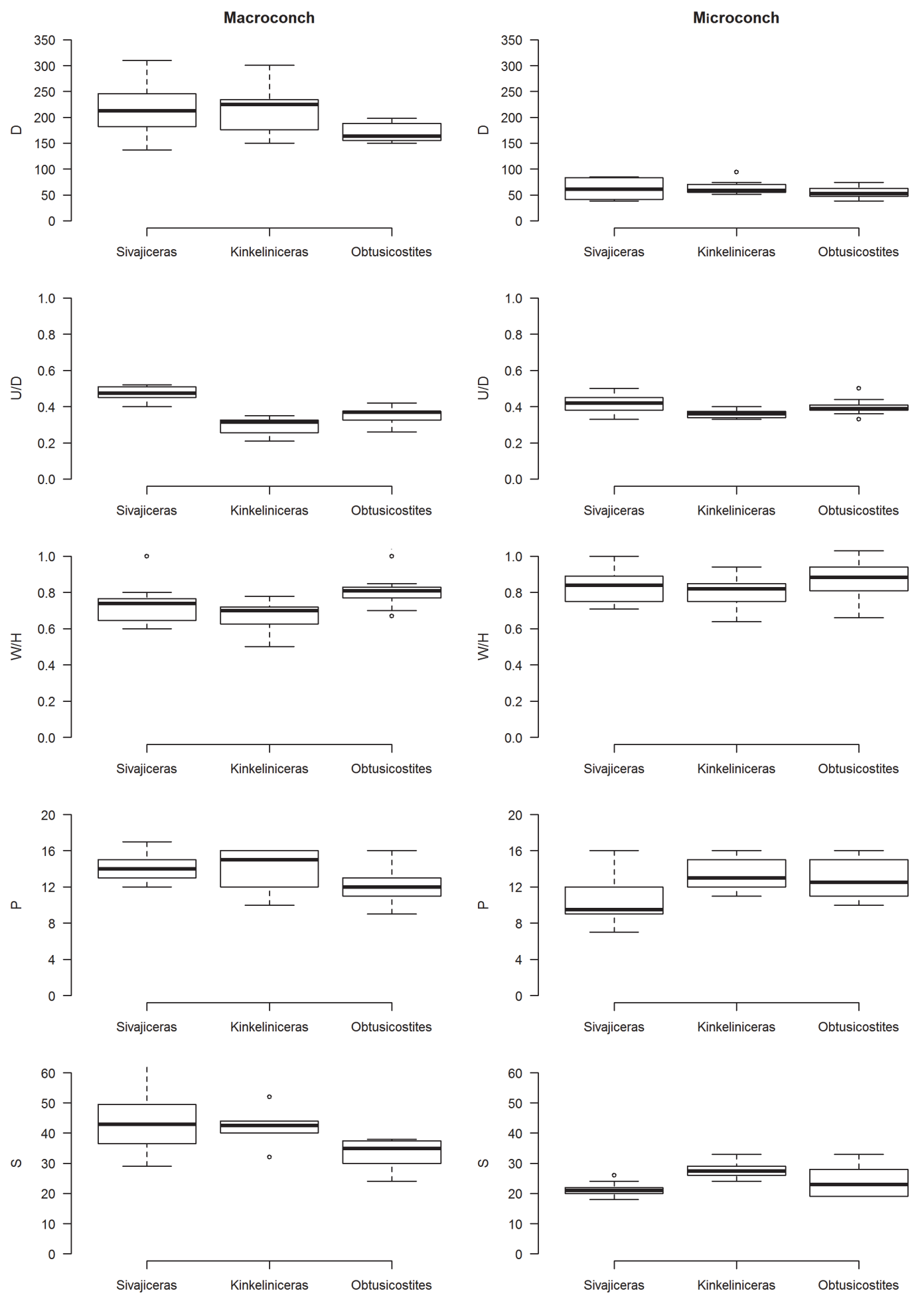

FIGURE 9. Parallel evolution of median values of different morphological characters for three successive genera (including $\mathrm{M}$ and $\mathrm{m}$ ) within Sivajiceratinae is plotted. Note that both $\mathrm{M}$ and $\mathrm{m}$ within the lineage show parallel evolutionary trends. $\mathrm{D}, \mathrm{U}, \mathrm{W}$, and $\mathrm{H}$ are the same as in Figure 4. $\mathrm{P}=$ Primary rib (per half whorl) and $\mathrm{S}=\mathrm{Secondary}$ rib (per half whorl). The dark horizontal line in the middle of the each box represents the median values, top frame of the box represents $75^{\text {th }}$ percentile, bottom frame of the box represents $25^{\text {th }}$ percentile and the bars at the end of vertical lines represent the minimum and the maximum data values without outliers (open circles). Sources are: Waagen, 1875; Spath, 1931; Collignon, 1958; Dutta and Bardhan, 2016. 

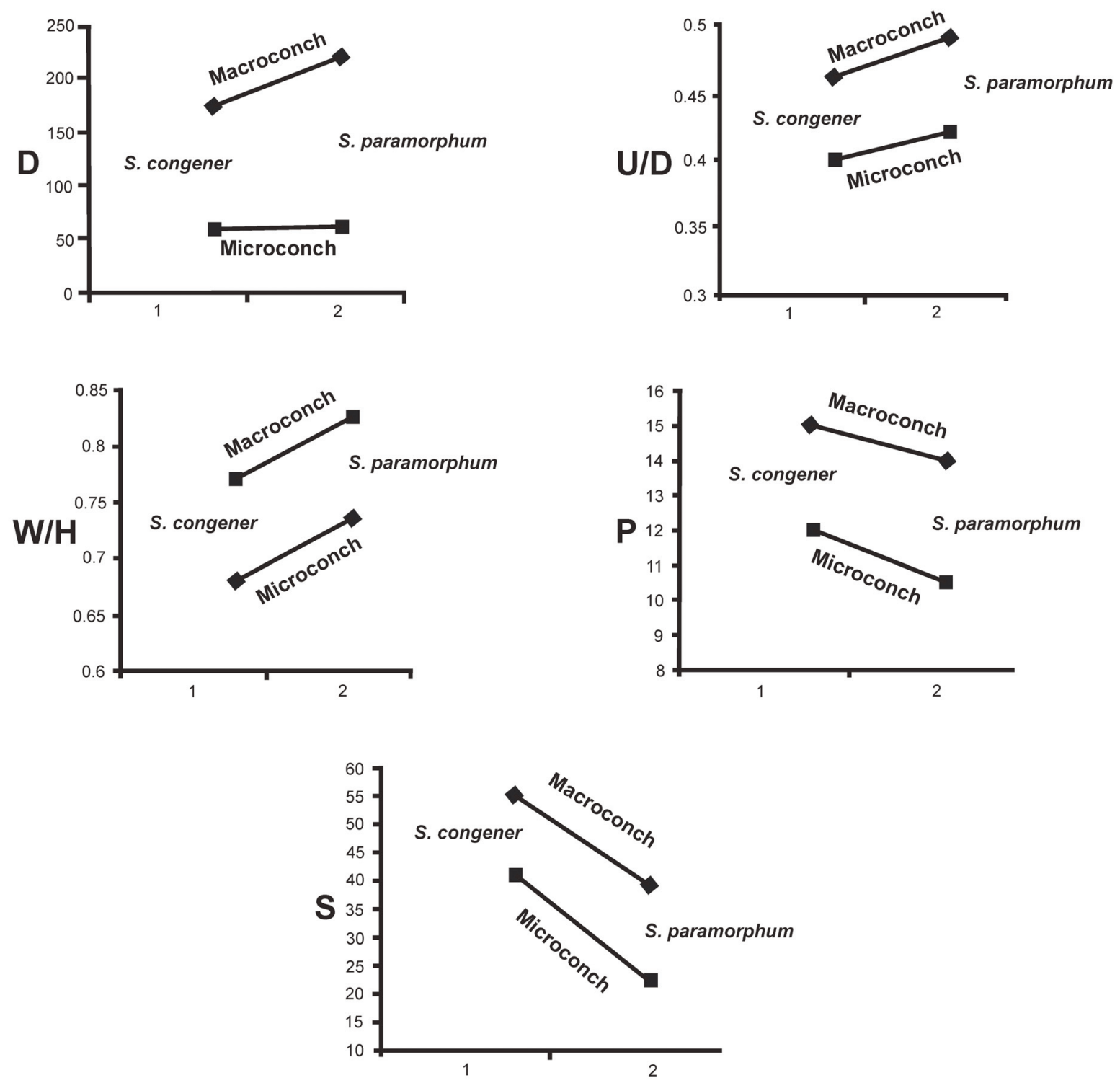

FIGURE 10. Parallel evolution of the species level for the genus Sivajiceras is plotted. Note that both $\mathrm{M}$ and $\mathrm{m}$ within the lineage show parallel evolutionary trends. Sources are: Waagen, 1875; Spath, 1931; Collignon, 1958; Callomon, 1993; Dutta and Bardhan, 2016.

dimorphic pair of Kinkeliniceras angygaster. The evolutionary loss of early constriction and rursiradiate ribbing, which were the apomorphic traits of Sivajiceras, was reflected both in the antidimorphic pairs of Obtusicostites and Kinkeliniceras (see Dutta and Bardhan, 2016).

\section{DISCUSSION}

Middle Jurassic witnessed maximum development of sexual dimorphism in ammonites when antidimorphs evoled contrasting characters leading to confusion for correct matching. Davis et al. (1996) also noted a significant increase of doubtful cases where it was very difficult to establish antidimorphic pairs especially during the Callovian. The same was true for the present Hubertoceras genus from Kutch.

Hubertoceras used to live sympatrically with macroconchiate genera, one of which ran a high chance of being the sexual partner. The contemporary macroconchiate genera were all large, evolute and strongly ornamented. Westermann (1990) collectively described them "trachyostracans" ammo- 

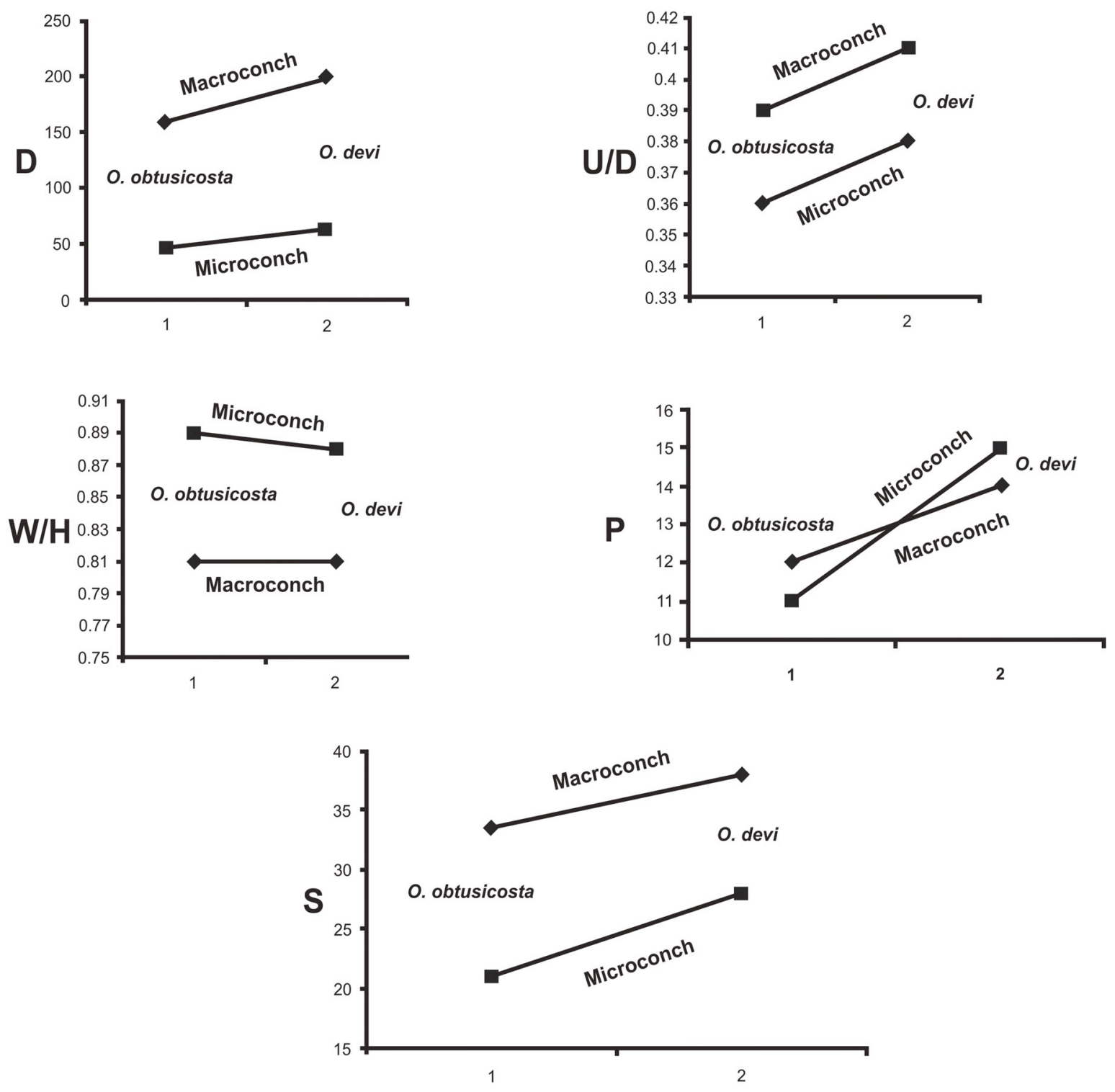

FIGURE 11. Parallel evolution of the species level for the genus Obtusicostites is plotted. Note that both $\mathrm{M}$ and $\mathrm{m}$ within the lineage show parallel evolutionary trends. Sources are: same as in Figure 10.

nites who lived in shallow waters (as was the Callovian Kutch basin; see Fürsich and Oschmann, 1993) and were nectobenthos (cf. Kennedy and Cobban, 1976; Batt, 1989; Tsujita and Westermann, 1998) and sluggish to moderately mobile (also see Ward, 1981; Seilacher and Gishlick, 2015). They were also strongly dimorphic whose microconchs were evolute, lappeted and having bifid ribs like Hubertoceras. This ammonite community faced competition for food, habitat and mates (Bardhan and Chattopadhyay, 2003; Jana et al., 2005). The functions of lappets have been variously interpreated (fabricational noise, Seilacher, 1974; Seilacher and Gishlick, 2015; change of hab- itat or behaviour, Westermann, 1990; Davis et al., 1996; Klug, 2001; defence against predation or intersexual cannibalism, Keupp and Riedel, 2010; sexual characters, Landman et al., 2012). Many workers, however, believed its utility to facilitate mate recognition system among other functions (Kennedy and Cobban, 1976; Jana et al., 2005; Bardhan et al., 2010; Keupp and Riedel, 2010).

Eldridge (1974) mentioned that while competing for the same habitat, sympatric taxa displayed character displacement (also see Jana et al., 2005). While macroconchs of all Kutch genera remained more or less "neutral" in having similar size, shape and ornaments, their microconchs 
diverge strongly away in their mature modifications. Similar size, perisphinctoid coiling (low whorl expansion rate with wide umbilicus), bifurcating ribs among the microconchs perhaps disrupted the "mate recognition" system (Bardhan et al., 2010). But, different types of lappets in different species (Figures 4-5) and absence of lappet in Idiocycloceras microconch perhaps, therefore, appeared as a sexual display, which facilitated easy recognition of the respective mates.

In conclusion, Hubertoceras Spath, 1931 of Kutch is a morph genus. Its microconchiate nature was established here based mainly on the presence of lappets. The antidimorph of Hubertoceras was elusive. Detailed search through morphological and morphometrical analyses including identical early ontogenetic characters as well as paleobiological and stratigraphic data suggests now that Obtusicostites represents the best macroconchiate match. The Obtusicostites-Hubertoceras dimorphic pair belongs to the Sivajiceratinae lineage where all genera are shown to be dimorphic. Evolutionary trends of many characters show parallelism between the macroconchs and the microconchs in the lineage.

\section{ACKNOWLEDGEMENTS}

We thank the Director of the Repository Section of the Geological Survey of India, Kolkata for granting access to the GSI material for study and photography. We acknowledge Z. Hughes for various supports and P. Hurst for the photography of type specimens housed in the Department of Earth Sciences, Natural History Museum, U.K. We thank C. Klug, University of Zurich, Switzerland for critically reviewing the manuscript and providing valuable suggestions. We thank the anonymous referee as well as the handling editor of the Journal for their critical reviews and suggestions. S.B. received partial aid from the DST (SERB-SR/S4/ ES-638/2012), India. R.D. received aid from the UGC-BSR Scheme, Jadavpur University, Kolkata, India.

\section{REFERENCES}

Arkell, W.J., Kummel, B., and Wright, C.W. 1957. Mesozoic Ammonoidea, p. L80-L437. In Moore, R.C. (ed.), Treatise on Invertebrate Paleontology, Part L, Mollusca 4. Geological Society of America and University of Kansas press, Lawrence, Kansas.

Bardhan, S. and Chattopadhyay, D. 2003. The Mesozoic marine revolution: an overview of a Biological 'Arms Race'. Indian Journal of Earth Sciences, 30:1-28.
Bardhan, S., Jana, K., and Roy, P. 2010. Sexual dimorphism and polymorphism in a Callovian Phlycticeras (Ammonoidea) assemblage of Kutch, India. Geobios, 43:269-281.

Bardhan, S., Dutta, R., Chanda, P., and Mallick, S. 2012. Systematic revision and sexual dimorphism in Choffatia (Ammonoidea: Perisphinctoidea) from the Callovian of Kutch, India. Palaeoworld, 21:29-49.

Batt, R. 1989. Ammonite shell morphotype distributions in the Western Interior Greenhorn Sea and some paleontological implications. Palaios, 4:32-42.

Bayle, E. 1878. Atlas I, Fossiles principaux des terrains. Memoires pour Servir a L'explication de la Carte Geologique Detaillée de la France, 4:1-158.

Bhaumik, D., Datta, K., Jana, S.K., and Bardhan, S. 1993. Taxonomy and intraspecific variation of Macrocephalites formosus (Sowerby) from the Jurassic Chari Formation, Kutch, western India. Journal of Geological Society of India, 41:163-179.

Biswas, S. K. 1977. Mesozoic rock-stratigraphy of Kutch. The Quarterly Journal of the Geological Mining and Metallurgical Society of India, 49:1-52.

Buckman, S.D. 1921. Type Ammonites, vol. III. William Wesley and Son, London, p. 33-40.

Callomon, J.H. 1963. Sexual dimorphism in Jurassic ammonites. Transactions of the Leicester Literary and Philosophical Society, 57:21-56.

Callomon, J.H. 1969. Dimorphism in Jurassic Ammonoidea. Some reflections, p. 111-125. In Westermann G.E.G (ed.), Sexual Dimorphism in Fossil Metazoa and Taxonomic Implications. International union of geological sciences. A 1 Schweizerbart, Stuttgart.

Callomon, J.H. 1981. Dimorphism in Ammonoids, p. 257-274. In House, M.R. and Senior, J.H. (eds.), The Ammonoidea. Academic Press.

Callomon, J. H. 1993. On Perisphinctes congener Waagen, 1875 and the age of the Patchman Limestone in the Middle Jurassic of Jumara, Kutch, India. Geologische Bla"tter fu"r Nordost-Bayern, 43:227-246.

Cariou, E. 1980. L' étage Callovien dans le Centre-Ouest de la France. I. Stratigraphie et paléogéographique. II. Les Reineckeiinae (Ammonitina) systématique, dimorphisme et évolution. Documents des Laboratoires de Géologie de la Faculté des Sciences de Lyon, 325:1-37, 1-790.

Cariou, E. 1984. Les Reineckeiidae (Ammonitina, Callovien) de la Téthys occidentale: systématique, dimorphisme et évolution. Etude à partir des gisements du Centre- Ouest de la France [in French]. Documents des Laboratoires de Géologie de la Faculté des Sciences de Lyon, 8:1-599.

Cariou, E. and Krishna, J. 1988. The Tethyan Reineckeiinae of Kachchh and Jaisalmer (West India): systematic, biostratigraphic and biogeographic implications. Palaeontographica Abteilung A, 149-170.

Collignon, M. 1958. Atlas des fossils caracteristiques de Madagascar. Fasc II (Bathonian-Callovian). Tananarive: Service Geologique. 
Cox, B.M. 1988. English Callovian (Middle Jurassic) Perisphinctid Ammonites. Part 1. Monograph of the Palaeontographical Society, London, 54 pp.

Cuvier, G. 1795. Second Mémoire sur l'organisation et les rapports des animaux à sang blanc, dans lequel on traite de la structure des Mollusques et de leur division en ordre, lu à la société d'Histoire Naturelle de Paris, le 11 prairial an troisième [30 May 1795]: Magazin Encyclopédique, ou Journal des Sciences, des Lettres et des Arts, 1795 [1. année], 2, p. 433449.

Datta, K. 1992. Facies, fauna and sequence: an integrated approach in the Jurassic Patcham and Chari Formations, Kutch, India. Unpublished PhD Thesis, Jadavpur University, Kolkata, India.

Datta, K., Bhaumik, D, Jana, S.K., and Bardhan, S. 1996. Age, ontogeny and dimorphism of Macrocephalites triangularis Spath - the oldest macrocephalitid ammonite from Kutch, India. Journal of the Geological Society of India, 47:44-458.

Davis, R.A., Landman, N.H., Dommergues, J.L., Marchand, D., and Bucher, H. 1996. Mature modifications and dimorphism in ammonoid cephalopods, p. 463539. In Landman, N.H., Tanabe, K., and Davis, R.A. (eds.), Ammonoid Paleobiology. Plenum, New York.

Donovan, D.T., Callomon, J.H., and Howarth, M.K. 1981. Classification of the Jurassic Ammonitina, p 101-155. In House, M.R. and Senior, J.R. (eds.), The Ammonoidea, Systematics Association by Academic press, London and New York.

Dutta, R. and Bardhan, S. 2016. Systematics, endemism and phylogeny of Indian proplanulitins (Ammonoidea) from the Bathonian-Callovian of Kutch, western India. Swiss Journal of Palaeontology, 135:23-56.

Dutta, R. and Bardhan, S. 2017. A taxonomic correction after 140 years (taxonomic note). Journal of Palaeontology, 9(1):194-198.

Eldredge, N. 1974. Character displacement in evolutionary time. American Zoologist, 14:1083-1097.

Fürsich, F.T. and Oschmann, W. 1993. Shell beds as tools in basin analysis: the Jurassic of Kachchh, western India. Journal of the Geological Society, 150:169-185.

Fürsich, F. T., Oschmann, W., Pandey, D. K., Jaitly, A. K., Singh, I. B., and Liu, C., 2004. Palaeoecology of Middle to lower Upper Jurassic macrofaunas of the Kachchh Basin, western India: an overview. Journal of the Palaeontological Society of India, 49:1-26.

Gould, S.J. and Vrba, E.S. 1982. Exaptation-a missing term in the science of form. Paleobiology, 8:4-15.

Howarth, M. K. 1992. The ammonite family Hildoceratidae in the Lower Jurassic of Britain. Monograph of the Palaeontographical Society, 145: 1-106.

Hyatt, A. 1900. Cephalopoda, p. 502-592. In Zittel, K.A. and Eastmann, C.R. (eds.), Textbook of Palaeontology, MacMillan, Boston.

Jana, S.K., Bardhan, S., and Sardar, S. K. 2000. Kheraiceras Spath (Ammonoidea)-new forms and records from the Middle Jurassic sequence of the Indian Subcontinent. Paleontological Research, 4:205-225.

Jana, S.K. 2002. Macrocephalitinae and Eucycloceratinae of the family Sphaeroceratidae (Ammonoidea) and other ancillary taxa from the Middle Jurassic of Kutch, western India: systematics, phylogeny and evolution. Unpublished PhD Thesis, Jadavpur University, Kolkata, India.

Jana, S., Bardhan, S., and Halder, K. 2005. Eucycloceratin ammonites from the Callovian Chari Formation, Kutch, India. Palaeonotology, 48:883-924.

Kayal, A. and Bardhan, S. 2005. The Middle Jurassic Reineckeiid ammonites: evolution and phylogenetic systematics at genus-group level. Indian Journal of Earth Sciences, 32:1-26.

Kayal, A. 2009. Palaeobiogeography, systematic and evolution of the Middle Jurassic family Reineckeiidae Hyatt and other ancillary ammonite taxa from Kutch, western India. Unpublished PhD Thesis, Jadavpur University, Kolkata, India.

Kennedy, W.J. and Cobban, W.A. 1976. Aspects of ammonite biology, biogeography, and biostratigraphy. Special Paper on Palaeontology, 17:1-94.

Kerr, J. P. and Kelley, P. H. 2015. Assessing the influence of escalation during the Mesozoic Marine Revolution: shell breakage and adaptation against enemies in Mesozoic ammonites. Palaeogeography, Palaeoclimatology, Palaeoecology, 440:632-646.

Keupp, H. and Riedel, F. 2010. Remarks on the possible function of the apophyses of the Middle Jurassic microconch ammonite Ebrayiceras sulcatum (Zieten, 1830), with a discussion on the palaeobiology of Aptychophora in general. Neues Jahrbuch für Geologie und Paläontologie, Abhandlungen, 255:301-314.

Klinger, H.C. and Kennedy, W.J. 1989. Cretaceous faunas from Zululand and Natal, South Africa. The Ammonite Subfamily Placenticeratidae Hyatt, 1900; with comments on the systematic position of the genus Hypengoceras Spath, 1924. Annals of the South African Museum, 98:241-408.

Klug, C. 2001. Life-cycles of Emsian and Eifelian ammonoids (Devonian). Lethaia, 34:215-233.

Klug, C., Zaton, M., Parent, H., Hostettler, H., and Tajika, A. 2015. Mature modifications and sexual dimorphism, p. 253-320. In Klug, C., Korn, D., De Baets, K., Kruta, I., and Mapes, R.H. (eds.), Ammonoid Paleobiology: From Anatomy to Ecology, Topics in Geobiology. Springer.

Landman, N.H., Cobban, W.A., and Larson, N.L. 2012. Mode of life and habitat of scaphitid ammonites. Geobios, 45:87-98.

Lehmann, U. 1971. New aspects in ammonite biology. Proceedings of North America Paleontology Convocation I, 1251-1269.

Linnaeus, C. 1758. Systema Naturae per Regna Tria Naturae, Secundum Classes, Ordines, Genera, Species, cum Characteribus, Differentiis, Synonymis, 
Locis. Editio decima, reformata. Laurentius Salvius: Holmiae, v. 2, 824 p.

Makowski, H. 1962. Recherches sur la dimorphisme sexuel chez les Ammonoides; Note preliminaire. Ksiega pam, ku czci Prof. J. Samsonowicza [Memory Book of Professor J. Samsonowicz], pp. 31-42. Warszawa.

Makowski, H. 1963. Problem of sexual dimorphism in ammonites. Palaeontologia Polonica, 12:1-92.

Monnet, C., De Baets, K., and Klug, C. 2011. Parallel evolution controlled by adaptation and covariation in ammonoid cephalopods. BMC Evolutionary Biology 11:115 http://www.biomedcentral.com/1471-2148/11/ 115.

Page, K. N. 2008. The evolution and geography of Jurassic ammonoids. Proceedings of the Geologists' Association, 119:35-57.

Roy, P. and Bardhan, S. 2007. Sexual dimorphism in Hecticoceras giganteum Spath ammonoidea) from the Callovian (Middle Jurassic) of Kutch, India. Neues Jahrbuch für Geologie und Paläontologie, Monatshefte, 245:263-272.

Roy, P., Bardhan, S., Mitra, A., and Jana, S.K. 2007. New Bathonian (Middle Jurassic) ammonite assemblages from Kutch, India. Journal of Asian Earth Sciences, 30:629-651.

Roy, A., Bardhan, S., Das, S., Mondal, S., and Mallick, S. 2012. Systematic revision and Palaeobiogeography of Perisphinctes indogermanus (Ammonoidea) from the Oxfordian of Kutch, India: Stratigraphic and Evolutionary Implications. Palaeoworld, 21:167-192.

Seilacher, A. 1974. Fabricational noise in adaptive morphology. Systematic Biology, 22:451-465.

Seilacher, A. and Gishlick, A. 2015. Morphodynamics. CRC press, Boca-Raton, Florida.

Shome, S. and Bardhan, S. 2009. The genus Umiaites Spath, 1931 (ammonoidea) from the Tithonian (Late Jurassic) of Kutch, western India. Palaeontologia Electronica, 12:1- 10. http://palaeo-electronica.org/ 2009_1/159/index.html.

Siemiradzki, J.V. 1898. Monographic description of the ammonite group Perisphinctidae. Palaeontographia, 45:69-296.

Spath, L. F. 1928. Revision of the Jurassic cephalopod fauna of Kachh (Cutch). Palaeontologia Indica, Geological Survey of India, New Series 9, Memoir 2:279550.

Spath, L. F. 1930. Revision of the Jurassic cephalopod fauna of Kachh (Cutch). Palaeontologia Indica, Geological Survey of India, New Series 9, Memoir 2:279550.

Spath, L.F. 1931. Revision of the Jurassic cephalopod fauna of Kachh (Cutch). Palaeontologia Indica, Geo- logical Survey of India, New Series 9, Memoir 2:279550.

Stanley, S.M. 1979. Macroevolution: Pattern and Process. Freeman, San Francisco.

Steinmann, G. 1890. Cephalopoda. In Steinmann, G. and Döderlein, L. (eds.), Elemente der Palaeontologie. W. Engelmann, Leipzig, pp. 344-475.

Thierry, J. 1978. Le genre Macrocephalites au Callovien Inferieur (Ammonites, Jurassique Moyen). Mémoires Géologiques Université de Dijon, 4.

Tsujita, C.J. and Westermann, G.E.G. 1998. Ammonoids habitats and habits in the Western Interior Seaway: a case study from the Upper Cretaceous Bearpaw Formation of southern Alberta, Canada. Palaeogeography, Palaeoclimatology, Palaeoecology, 144:135160.

Vermeij, G.J. 1977. The Mesozoic marine revolution: evidence from snails, preclators and grazers. Paleobiology, 3:245-258.

Vermeij, G.J. 1987. Evolution and Escalation. Princeton University Press, Princeton, N.J.

Vermeij, G. 2002. Evolution in the consumer age: predators and the history of life. Paleontological Society Papers, 8:375-394.

Waagen, W. 1869. Die Formenreihe des Ammoniten subradiatus. Geognostische Palaeontologische Beiträge, 2:181-256.

Waagen, W. 1875. Jurassic fauna of Kutch. Palaeontologia Indica. Geological Survey of India, Memoir 9:247.

Ward, P. 1981. Shell structure as a defensive adaptation in ammonoids. Palaeobiology, 7:96-100.

Westermann, G.E.G. 1990. New developments in ecology of Jurassic-Cretaceous ammonoids, p. 459-478. In Pallini, G., Cecca, F., Cresta, S., and Santontonio, M. (eds.), Atti del Secondo Convegno Internazionale Fossili, Evolutione, Ambiente, Pergola, 1987.

Wright, C.W., Callomon, J.H., and Howarth, M.K. 1996. Cretaceous Ammonoidea. In Kaesler, R.L. (ed.), Treatise on invertebrate paleontology, Part L, Mollusca 4 (revised). GSA and University of Kansas Press, Lawrence.

Wynne, A.B. 1872. Memoire on the geology of Kutch to accompany a map compiled by A.B. Wynne and F. Fedden, during the seasons 1867-68 and 1868- 69. Memoirs of the Geological Survey of India, 9:1-294.

Zittel, K.A. 1884. Handbuch der Palaeontologie. Oldenbourg, Munich and Leipzig, pp. 329-522.

Zuschin, M., Stachowitsch, M., and Stanton, R. 2003. Patterns and processes of shell fragmentation in modern and ancient marine environments. Earth Science Reviews, 63:33-82. 


\section{APPENDIX 1.}

Locality, stratigraphic information and measurements of all specimens (type as well as additional present collection) of Sivajiceratinae within the mainland of Kutch. For detail information of localities see Spath (1931); Waagen (1875); Figure 1. Available in PDF at palaeo-electronica.org/content/2017/1954-antidimorph-of-hubertoceras.

\section{APPENDIX 2.}

Precise stratigraphy and locality information of the all the specimens of Obtusicostites and Hubertoceras. Available in PDF at palaeo-electronica.org/content/2017/1954-antidimorph-ofhubertoceras.

\section{APPENDIX 3.}

Stratigraphic information and measurements of all contemporary macroconchiate (middle Callovian) species of different genera along with Hubertoceras (m). Available in PDF at palaeo-electronica.org/content/2017/1954-antidimorph-of-hubertoceras.

\section{APPENDIX 4.}

Results of Mann-Whitney $U$ test for testing significance of change in morphological traits. Available in PDF at palaeo-electronica.org/content/2017/1954-antidimorph-of-hubertoceras. 